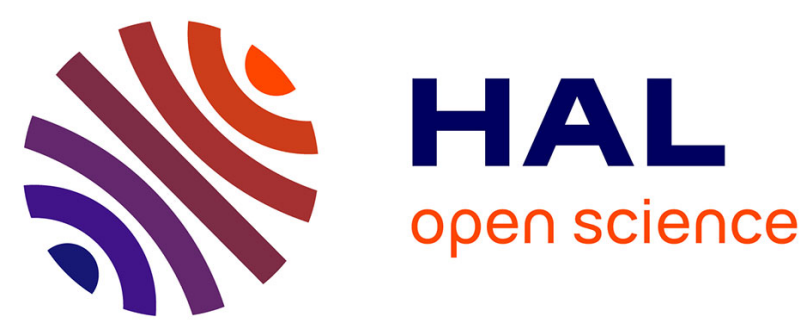

\title{
Paleo-Tethyan Evolution of Tibet as Recorded in the East Cimmerides and West Cathaysides
}

Zhiqin Xu, Yildirim Dilek, Hui Cao, Jingsui Yang, Paul Robinson, Changqian Ma, Huaqi Li, Marc Jolivet, Françoise Roger, Xijie Chen

\section{- To cite this version:}

Zhiqin Xu, Yildirim Dilek, Hui Cao, Jingsui Yang, Paul Robinson, et al.. Paleo-Tethyan Evolution of Tibet as Recorded in the East Cimmerides and West Cathaysides. Journal of Southeast Asian earth sciences, 2015, 105, pp.320-337. 10.1016/j.jseaes.2015.01.021 . insu-01119604

\section{HAL Id: insu-01119604 https://hal-insu.archives-ouvertes.fr/insu-01119604}

Submitted on 23 Feb 2015

HAL is a multi-disciplinary open access archive for the deposit and dissemination of scientific research documents, whether they are published or not. The documents may come from teaching and research institutions in France or abroad, or from public or private research centers.
L'archive ouverte pluridisciplinaire HAL, est destinée au dépôt et à la diffusion de documents scientifiques de niveau recherche, publiés ou non, émanant des établissements d'enseignement et de recherche français ou étrangers, des laboratoires publics ou privés. 


\section{Paleo-Tethyan Evolution of Tibet as Recorded in the East Cimmerides and West Cathaysides}

Zhiqin $\mathrm{Xu}^{\mathrm{a}, *}$, Yildirim Dilek ${ }^{\mathrm{a}, \mathrm{c}}$, Hui Cao ${ }^{\mathrm{a}}$, Jingsui Yang ${ }^{\mathrm{a}}$, Paul Robinson ${ }^{\mathrm{d}}$, Changqian $\mathrm{Ma}^{\mathrm{e}}$, Huaqi $\mathrm{Li}^{\mathrm{a}}$, Marc Jolivet ${ }^{\mathrm{f}}$, Françoise Roger ${ }^{\mathrm{g}}$, Xijie Chen ${ }^{\mathrm{a}}$

${ }^{a}$ State Key Laboratory of Continental Tectonics and Dynamics, Institute of Geology, Chinese Academy of Geological Sciences, Beijing 100037, China

${ }^{b}$ State Key Laboratory for Mineral Deposits Research, Department of Earth Sciences, Nanjing University, Nanjing 210093, China

'Department of Geology \& Environmental Earth Science, Miami University, Oxford, OH 45056, USA

${ }^{\mathrm{d}}$ Department of Earth Sciences, Dalhousie University, Halifax, Nova Scotia, Canada B3H4J1

${ }^{\mathrm{e}}$ China University of Geosciences, Wuhan 430074, China

${ }^{\mathrm{f}}$ UMR 6118 - CNRS - University Rennes 1, Campus de Beaulieu, 35042 RENNES Cédex, France

${ }^{8}$ Université Montpellier 2, Place Eugène Bataillon, 34095 Montpellier Cedex 05, France

\section{Corresponding Author:}

Dr. Zhiqin Xu

Tel.: +86-01068999663

Email: xuzhiqin@gmail.com

\section{Submitted to:}

Journal of Asian Earth Sciences

Re-revised Ms: January 12, 2015 


\section{Abstract}

The Paleozoic-early Mesozoic geology of Tibet was controlled by the rift-drift, seafloor spreading and subduction zone tectonics of a Paleo-Tethyan realm, which evolved between the West Cathaysides (WC) and the East Cimmerides (EC). Different suture zones with ophiolites and ophiolitic mélanges, high-pressure metamorphic belts, magmatic arcs and accretionary prism complexes separating different terranes mark multiple subduction-accretion systems within this Paleo-Tethyan domain, reminiscent of the modern Western Pacific Ocean. Discrete basins separated by different continental blocks and magmatic arcs constituted a complex paleogeography of Paleo-Tethys, and these oceanic strands were closed as a result of subduction with different polarities during the late Paleozoic-Triassic. The Longmu Tso Shuanghu-Changning Menglian Suture zone (LS-CMS) in Tibet represents the main tectonic boundary between the WC and EC that developed in the Devonian. The East Kunlun-A'nyemaqen oceanic slab was subducted northward beneath the East Kunlun terrane in northern Tibet, whereas the Sumdo oceanic slab was subducted northward beneath the South Qiangtang-North Lhasa terrane in southern Tibet. The Longmu Tso Shuanghu-Changning Menglian and Jinshajiang-Ailaoshan-Song Ma ophiolites were developed and emplaced in subductionaccretion systems with opposite polarities (westward and eastward) beneath the North Qiangtang-Qamdo-Simao-Indochina terrane in central Tibet. The Jinshajiang-AilaoshanSong Ma oceanic slab was subducted westward beneath the North Qiangtang-SimaoIndochina terrane along the Jinshajiang and Ailaoshan-Song Ma trenches in a trenchridge-trench triple junction plate configuration. The Emeishan mantle plume produced a large Permian basaltic terrane, developed on the western passive margin of the South China block. The final closure of the Paleo-Tethyan oceanic branches resulted in continental collisions and development of a vast Indosinian orogenic collage in the latest Triassic-Jurassic.

Key words: Paleo-Tethyan Tibet; Orogenic collage; Cimmerides; Cathaysides; Paleo-Tethys; Ophiolites and suture zones; Décollement-type orogen 


\section{Introduction}

Reconstructions of Pangea and Tethys for the time interval of 295-200 Ma (Fig. 1; Dilek and Rowland, 1993; Dilek et al., 1999; Dilek and Robinson, 2003; Flower and Dilek, 2003; Scotese, 2004; Metcalfe, 2011, 2013) indicates that the Paleo-Tethyan and Neo-Tethyan oceanic realms developed in the wake of northward-drifting ribbon continents and continental masses that were rifted off from the northern edge of Gondwana (Fig. 1; Dilek and Rowland, 1993; Dilek et al., 1999; Dilek and Robinson, 2003; Scotese, 2004; Metcalfe, 2011, 2013). The Cimmerides represent one of these continental masses whose remnants are now found in Anatolia, Persia, Afghanistan and Tibet (Metcalfe, 1996a, b; Metcalfe, 1999; Fig. 1). The Cathaysides included mainly the South China, Indochina, Sibumasu and Qamdo continental blocks and were already part of the Paleo-Tethyan realm since the Sedonian (Wegener, 1912; Morel and Irving, 1981; Parrish, 1993; Collins et al., 2003). The evolution of Paleo-Tethys, as recorded in the geology of Tibet, was controlled to the largest extent by the tectonic interactions between the Cathaysides and the Cimmerides during much of the late Paleozoic-early Mesozoic. The Gondwana-derived terranes that are currently separated by a series of suture zones in Tibet migrated across the Paleo-Tethyan Ocean and were accreted into Asian continental margins during the late Paleozoic and Mesozoic. The final closure of the Paleo-Tethyan Ocean resulted in collision of the East Cimmerides and the West Cathaysides in Tibet, and led to the development of a vast orogenic belt (indosinian orogenic belt) in South Asia (Fromaget, 1927, 1929, 1934, 1952; Huang, 1945; Ren and Qu, 1966).

A new Permian paleogeographic reconstruction of northern Peri-Gondwana and Paleo-Tethys with a focus on Tibet (Fig. 2; Metcalfe, 2002) indicates that Permian marine strata occurred in an array of blocks containing diverse faunas of different biogeographical affinities. The North Qiangtang-Qamdo Block contains Permian marine faunas of typically Cathaysian character, whereas the Himalaya Tethys zone in southern Tibet is characterized primarily by cold-water faunas. The South Qiangtang and Lhasa blocks are characterized by mixed warm- and cold-water faunas supplemented with a strong endemic component (Zhang et al., 2013). 
In this paper, we present an overview of the tectonic evolution of Paleo-Tethys as recorded in the geological history of the East Cimmerides and West Cathaysides. We examine the structure and geochronology of different continental blocks, island arcs and magmatic arcs, accretionary prism complexes, ophiolites and suture zones that collectively represent the Paleozoic-early Mesozoic geology of the East Cimmerides and West Cathaysides, and the Paleo-Tethyan oceanic strands in between them. This overview and the tectonic model presented in the last part of the paper are based on the extant literature and our own work in Tibet and in the surrounding regions. As we review the existing and new data on the Paleo-Tethyan evolution of Tibet, we focus on the following fundamental questions related to its Paleo-Tethyan tectonics: (1) How does the geology of the East Cimmerides (EC) and West Cathaysides (WC) reflect the PaleoTethyan tectonics in Tibet? (2) What were the timings of the opening and the closure of different strands of the Paleo-Tethyan Ocean, and what were the subduction polarities within them as they closed? (3) How did the amalgamation of various continental blocks and arc terranes within the Paleo-Tethyan realm occur, leading to the final closure of Paleo-Tethys and to the development of the Indosinian orogenic collage?

\section{Paleo-Tethyan tectonic framework in Tibet}

The Paleo-Tethyan realm in Tibet can be subdivided, based on the occurrence of markedly distinct Permian and younger sedimentary sequences and faunal successions in them (Ueno et al., 2003; Zhang et al., 2013), into two main domains: The East Cimmerides to the west and the West Cathaysides to the east (Metcalfe, 1999). The East Cimmerides includes the South Qiangtang/North Lhasa (SQT-NLS) - Baoshan (BS) Sibumasu (SB) terranes to the north and the South Lhasa terrane to the south (Fig. 3). The West Cathaysides in Tibet includes the North Qiangtang-Qamdo-Simao-Indochina and Songpan-Ganze terranes (Fig. 3). The final collision between the East Cimmerides and West Cathaysides resulted in the build-up of a broad Paleo-Tethyan (or Indosinian) orogenic belt during the latest Triassic and Jurassic (Xu et al., 2013) that is characterized by multiple ribbon terranes, Paleozoic ophiolites, island arc complexes, high pressure metamorphic belts, and fossil accretionary prism complexes. 
Major fault systems separating these various tectonic entities in Tibet developed during their juxtaposition as the Paleo-Tethyan oceanic realm diminished. The Longmu Tso Shuanghu-Changning Menglian suture zone, which separates the East Cimmerides from the West Cathaysides (Fig. 3), represents the most important suture zone within the Paleo-Tethyan system in Tibet. The E-W trending Kunlun-A'nyemaqen suture zone in the West Cathaysides lies between the Songpan Ganze terrane to south and the Kunlun terrane to north, and the Jinshajiang-Ailaoshan-Song Ma suture zone separates the North Qiantang-Qamdo-Simao-Indochina terrane from the South China Block and the Songpan Ganze terrane (Fig. 3). The newly discovered Paleo-Tethyan Sumdo suture zone occurs between the South Qiangtang-North Lhasa and South Lhasa terranes of southern Tibet (Fig. 3; Yang et al., 2006; Chen et al., 2009). Numerous ophiolites and ophiolitic mélanges, high-pressure metamorphic units, magmatic arcs, and accretionary wedges with abundant exotic blocks are exposed along all these suture zones (Xu et al., 2013).

Accretionary orogens related to oceanic subduction develop at intraoceanic and continental convergent margins and include forearc, arc and backarc components (Dilek, 2006; Cawood et al., 2009a, b). Accretionary orogens are variably deformed and metamorphosed through subduction processes and tectonothermal events, as commonly recorded in sub-parallel, high-T-high-P belts (Miyashiro, 1973; Ernst, 2005; Brown, 2006, 2009). Paleo-Tethyan subduction systems (i.e. magmatic arc terranes and accretionary complexes) in Tibet occur along several well-recognized suture zones. Paleo-Tethyan arc terranes and subduction-accretionary wedges are exposed in central and south-southeastern Tibet, including the Lincang arc terrane on the eastern side of the Changning-Menglian suture zone, the Yidun arc terrane between the Jinshajiang and Litang suture zones, the Bulhanbuda Arc and West Qinling accretionary wedge on the northern side of the East Kunlun-A'nyemaqen suture zone, as well as the Sumdo subduction-accretionary terrane between the South Qiangtang-North Lahasa and South Lhasa terranes.

\subsection{Paleo-Tethyan terranes in Tibet}

\subsubsection{West Cathaysides (WC)}


The West Cathaysides in Tibet consist of the Songpan-Ganze and the North Qiangtang-Qamdo-Simao-Indochina terranes, which are connected with the ProtoTethyan Qilianshan-Qadam-East Kunlun terranes to the north and with the South China Block to the east (Fig. 3).

Songpan-Ganze (SPGZ) terrane: The Songpan-Ganze terrane is separated from the Paleo-Tethyan Qilian-East Kunlun terrane to the north by the A'nyemaqen suture zone, the North Qiangtang-Qamdo-Simao-Indochina terranes to the southwest by the Jinshajiang suture zone, and the Yangtze block to the east by the Longmen Shan suture zone.

The Triassic Songpan-Ganze orogeny resulted from plate boundary interactions between the Yangtze, North China, and Qiangtang blocks during the closure of the Paleo-Tethyan Ocean. The orogenic belt is composed mainly of, from west to east, the Bayan Har, Songpan-Ganze, Yidun (or Litang-Batang) and Longmenshan terranes. The Songpan-Ganze terrane is divided by the NW-SE-oriented Xiangshuihe fault into two parts: the Danba Unit to the east and Muli Unit to the west that are composed of Precambrian basement rocks and Paleozoic-Triassic cover series (Xu et al., 1992; Roger et al., 2004).

The Songpan-Ganze terrane includes a Middle Upper Triassic flysch unit and preTriassic rocks (Xu et al., 1992). The Triassic flysch unit occupies a triangular-shaped area between the East Kunlun terrane to the north, the Longmen Shan to the east and the Yidun arc terrane to the southwest, and consists of more than 10-km-thick clastic rock sequences. It has been considered to represent a giant fan deposit, analogous to the modern Bengal fan in the Indian Ocean. Triassic-Jurassic clastic sedimentary rocks occur to the east of the flysch units, and are highly deformed. They are similar in age and lithology to those clastic rock units in the Yangtze Block.

The Neoproterozoic basement crops out only in the southeastern part, in the Danba, Muli, Xuelongbao and Longmen-Shan areas (Xu et al., 1992; Roger and Calassou, 1997; Zhou et al.2002, 2006a, b), and consists mainly of a crystalline complex with ages around 748-884 Ma (Roger et al., 2004). The late Proterozoic granitoids represent calcalkaline intrusions that formed above a south-dipping subduction zone beneath the 
Yangtze block during 1000-850 Ma (Gao et al., 1990; Kröner et al., 1993). The nature of the basement below the Triassic sedimentary basin to the north remains unknown.

The Songpan Ganze terrane does not represent a typical collisional orogeny. The large volume of accreted Triassic sedimentary rocks between the North China, Qiangtang and Yangtze did not allow a complete continent-continent collision (Roger et al., 2004). Major tectonic structures in Longmen Shan of the eastern margin of the Tibetan plateau have been reactivated by strike-slip faults during the Tertiary.

The Songpan-Ganze terrane is juxtaposed against the Tianshuihai terrane in the west along the NE-SW-striking, sinistral Altyn Tagh fault. The Tianshuihai terrane is bounded by the West Kunlun terrane to the north and the West Qiangtang terrane to the south, separated by the nearly E-W-extending West Kunlun suture zone and the NWSE-running Kalakunlun fault, respectively. The pre-Sinian metamorphic basement of the Tianshuihai terrane is exposed in its northwestern part, consisting of medium- to highgrade granulite to amphibolite-facies rocks. In the early Paleozoic, the Tianshuihai region was covered predominantly by continental slope facies and turbiditic clastic deposits, calcareous mudstones of a flysch sequence, and abyssal deposits. Subsequently, all these units were deformed and metamorphosed during an early Paleozoic orogeny, followed by the deposition of Upper Devonian foreland basin sedimentary rocks, consisting of marine and terrestrial molasse deposits (Ding et al., 1996). A thick, PermoTrassic flysch succession represents a Paleo-Tethyan product. All these units were subsequently deformed during the Indosinian orogeny. Post-orogenic granites were emplaced at 246-190 Ma (Arnaud, 1992; Xu et al., 1992).

North Qiangtang-Qamdo-Simao-Indochina terrane: The North QiangtangQamdo-Simao-Indochina terrane is bounded by the Jinshajiang-Ailaoshan-Song Ma suture zone to the north and the east, and by the Longmu Tso Shuanghu-Changning Menliang suture zone to the south and the west. It is located between the SongpanGanze and South Qiangtang-North Lhasa-Baoshan-Subumasu terranes (Fig. 3).

The Qiangtang terrane has been divided into northern and southern sub-regions based on the recent discovery and identification of the Longmu Tso-Shuanghu PaleoTethyan suture zone. Based on the results of paleontological studies of the fauna and 
flora, the Longmu Tso-Shuanghu and Changning-Menglian suture zones can be combined to represent the boundaries of the West Cathaysides and the East Cimmerides, separating the North Qiangtang-Qamdo-Simao-Indochina terrane and the South Qiangtang-Baoshan-Sibumasu terrane.

The North Qiangtang-Qamdo-Simao-Indochina terrane consists mainly of Upper Paleozoic and Mesozoic sedimentary rocks, overlain by Cenozoic basinal strata. The metamorphic basement of the Amugang Group includes 519-530 Ma gneisses and is distributed mainly in the southern margin of the terrane (Chang et al., 1986; Xu et al., 1997). In the Ordovician-Permian, the Qiangtang terrane was located in the northern margin of Gondwana, characterized by a succession of littoral-neritic clastic and carbonate rocks. From the early Trassic onwards, the tectonic evolution of the Qiangtang terrane began to change following the formation of the Indosinian orogenic belt. In the middle-late Trassic, a transgressional event occurred in the Qiangtang region, and a succession of neritic-littoral carbonate and clastic rocks was deposited with a thickness ranging from several kilometers to ten-thousand meters. Nearly 9000-m-thick continental clastic and volcanic rocks of the Upper Triassic Batang Group formed in the northeastern margin (Yushu region). In the Jurassic, as a result of extension in the Bangonghu-Nujiang Ocean, the North Qiangtang terrane was transformed into a continental marginal sea, covered by 4000- to 5000-m-thick sediments (Xu et al., 2007).

In the middle Jurassic, the North Qiangtang oceanic basin continued to extend. In contrast, in the late Jurassic, widespread regression took place in the Qiangtang region, indicated by the existence of 500-m-thick Upper Jurassic neritic-littoral sedimentary rocks, which were the final trace of marine depositional facies in the Qiangtang terrane. The occurrence of late-Middle Jurassic terrestrial deposits implies that the North Qiangtang terrane began to emerge as a landmass at this time. The tectonic evolution of the entire North Qiangtang terrane was characterized by uplift, erosion and exhumation during the Cretaceous. In the Mesozoic, the North Qiangtang terrane was subject to two episodes of orogeny. Subsequently, voluminous alkaline lavas were erupted in the Kekexili region in the Miocene. Regional seismic tomographic interpretations suggest that this volcanism was associated with upwelling of a mantle diapir (Xu et al., 1999). 


\subsubsection{East Cimmerides (EC) in Tibet}

During the Carboniferous-Permian, the South Qiangtang and the North Lahasa terranes belonged to the faunal and floral provinces of the West Cathaysides and the East Cimmerides, respectively. Opening of a branch of Neo-Tethys between the South Qiangtang and North Lahasa terranes was initiated in the Trassic after the termination of the Paleo-Tethyan regime. This Neo-Tethyan strand was closed in the early Cretaceous along the Bangonghu-Nujiang suture zone. The Lhasa terrane is subdivided into the South Lhasa and North Lhasa terranes along the Sumdo Paleo-Tethyan suture zone in central Lhasa (Yang et al., 2006).

The South Lhasa terrane is composed of a Precambrian crystalline basement, Paleozoic to Mesozoic sedimentary strata, and Paleozoic magmatic rocks. This terrane has long been accepted as the last crustal block to be accreted to Asia prior to its collision with northward drifting Indian continent in the Cenozoic (Zhang et al., 2014). Recent results have shown that the Lhasa terrane experienced multi-stage metamorphic, magmatic and tectonic events. The north Lhasa terrane includes Neoproterozoic oceanic crustal rocks, late Cryogenian ( $\sim 650 \mathrm{Ma})$ high-P metamorphic units, early Paleozoic ( 485 Ma) medium-P metamorphic rocks, and early Paleozoic magmatic sequences, collectively representing an Andean-type orogenic belt produced from subduction of the Paleo-Tethyan ocean floor (Zhang et al., 2014). The Songduo formation includes schists, marble and eclogite with 260 Ma high-P metamorphic and $220 \mathrm{Ma}$ retrograde metamorphic ages, and is distributed in the northern margin of the South Lhasa terrane.

Voluminous Andean-type magmatism (Gangdese magmatic arc) and syn- to postcollisional volcanism took place in the Mesozoic and Cenozoic as a result of the subduction of the Neo-Tethyan oceanic lithosphere during and after the India-Eurasian collision, respectively. Plutonic and volcanic rocks associated with these magmatic events were constructed on and across the Paleo-Tethyan orogenic crust and structures. Collision-driven surficial and crustal uplift facilitated the exhumation of the root of the Andean-type magmatic arc (170-80 Ma) and of the high-T/medium-P metamorphic rocks in the northern Himalaya and southern Tibet. 


\subsection{Paleo-Tethyan suture zones in Tibet}

Four major Paleo-Tethyan suture zones exist in Tibet. These are: Longmu Tso Shuanghu-Changning Menglian, Jinshajiang-Ailaoshan-Song Ma, East KunlunA'nyemaqen, and Sumdo Suture zones. We describe below these suture zones based on their formation in succession of the Paleo-Tethyan ocean basins.

\subsubsection{Main Paleo-Tethyan suture zones between the East Cimmerides and West} Cathaysides

Longmu Tso Shuanghu-Changning Menglian Suture Zone (LS-CMS): The curvilinear Longmu Tso-Shuanghu-Changning Menglian Suture Zone extends from the E-W striking Longmu Tso-Shuanghu suture zone in central Tibet to the N-S striking Changning Menglian suture zone in SE Tibet between the East Cimmerides and West Cathaysides (Li et al., 1995, 2006a, b; Zhong, 1998; Metcalfe, 2006, 2013; Xu et al., 2013). The Changning Menglian suture zone connects with the Inthanon and Sara Kaeo suture zones in the south (Fig. 3; Lepvrier et al., 2008). Considering the distinct Permian sedimentary sequences and faunal successions of the Cimmerides and Cathaysides, (Metcalfe, 2002; Zhang et al., 2013), we interpret the Longmu Tso ShuanghuChangning Menglian suture zone as the main Paleo-Tethyan suture zone (Li, 1987; Li et al., 1995; Metcalfe, 2006; Zhang et al., 2006a, b; 2011; Zhai et al., 2011a, b).

The Paleo-Tethyan subduction system is characterized by a high-P metamorphic zone in the subduction-accretion complex along the Longmu Tso Shuanghu-Changning Menglian suture zone, as well as magmatic arc terranes, such as the Longmu TsoShuanghu terrane in the north and Linchang terrane in the south.

Longmu Tso Shuanghu suture zone in the northern part of the Longmu Tso Shuanghu-Changning Menglian Suture Zone: The Qiangtang terrane is divided into Northern and Southern parts, separated by a high-P metamorphic belt and ophiolites in the E-W-trending Longmu Tso-Shuanghu suture zone (LSS) (Li et al., 2006; Zhai et al., 2011a, b) in the central part of the Qiangtang terrane. This suture zone merges with the N-S-trending Changning Menglian suture zone in southeastern Tibet (Fig. 3). The 
basement of the South Qiangtang terrane is composed mainly of 591-470 Ma orthogneisses that are unconformably overlain by Ordovician slates with a basal conglomerate and a Carboniferous classic sedimentary sequence. Thus, the basement of the South Qiangtang is similar to the Lhasa and Himalaya terranes in southern Tibet, and to the Tengchong and Baoshan terranes in southeastern Tibet (Zhao et al., 2014).

The Longmu Tso Shuanghu suture zone contains ophiolites and ophiolitic mélanges, ocean island-type basalts (OIB), high-P metamorphic rocks, DevonianPermian radiolarian cherts, and accretionary prism complexes (Li et al., 1995; Kapp et al., 2003; Zhai et al., 2007, 2011a, b). Based on the existing U-Pb zircon ages of 467$438 \mathrm{Ma}$ from a cumulate gabbro (Li et al., 2008; Zhai et al., 2010) and of 357-345 Ma from gabbro and plagiogranite rocks in the ophiolites along the Longmu Tso Shuanghu suture zone (Zhai et al., 2013a, b, c), we infer that a strand the Paleo-Tethyan Ocean existed between the North Qiangtang and South Qiangtang terranes in the DevonianCarboniferous.

A >500-km-long, high-P metamorphic belt, composed of eclogite and blueschist, occurs in the Gemu-Gangma Tso, Shuanghu, Baqing and Jitang areas along the Longmu Tso Shuanghu suture zone (Kapp et al., 2003; Li et al., 2005, 2006; Pullen et al., 2008; Zhai et al., 2011a, b; Zhao et al., 2014). P-T calculations show that peak metamorphism in the belt took place at $2.0-2.5 \mathrm{GPa}$ and $410-460^{\circ} \mathrm{C}$, equivalent to a depth of $60-80 \mathrm{~km}$ (Zhai et al., 2011b). U-Pb zircon ages of 237-230 Ma (Zhai et al., 2011a, b) and Lu-Hf mineral isochron ages of 233-244 Ma from an eclogitic rock in the belt (Pullen et al., 2008) show that high-P rocks in this belt may have formed during the main period of subduction of the Paleo-Tethyan ocean floor. The exhumation ages of these high-P metamorphic rocks are dated by ${ }^{40} \mathrm{Ar} /{ }^{39} \mathrm{Ar}$ ages at $220 \mathrm{Ma}$ for phengite separates from an eclogite, at 223-227 Ma for amphibole separates from an amphibolite, and at 222-203 Ma for mica separates from blueschist rocks (Zhai et al., 2011a,b).

A magmatic arc belt composed of volcanic rocks and dioritic plutons is exposed along the northern side of the Longmu Tso-Shuanghu metamorphic zone. These rocks have adakitic geochemical affinities and appear to have formed between 223 and 205 Ma in the late Triassic (Zhai et al., 2013a, b, c). Based on new Hf and U-Pb isotopic dating results and zircon REE analyses, Yang et al. (2011) proposed that this magmatic 
belt was built as a result of northward subduction of the Paleo-Tethyan oceanic lithosphere beneath the North Qiangtang terrane in the Triassic.

The Longmu Tso Shuanghu arc terrane (LSA) is a discontinuous magmatic belt associated with an accretionary prism along the northern Longmu Tso Shuanghu suture zone. Granitic plutons in the Longmu Tso Shuanghu arc have revealed U-Pb zircon ages of 275-248 Ma (Yang et al., 2011).

\subsubsection{Changning Menglian Suture Zone and its Paleo-Tethyan subduction system}

The N-S-trending Changning Menglian suture zone was first recognized by Huang et al. (1984), who interpreted it as a remnant of a pre-Permian ocean basin that separated the Baoshan-Shan block (Sibumasu terrane) from the other terranes to the east. Huang et al. (1984) regarded this suture as a branch of the Jinsha-Tengliao River suture zone. The Changning Menglian suture zone is currently recognized as an important terrane boundary (Fig. 2) (Chen et al., 1987; Charusiri et al., 1993; Peng et al., 2006a, b; Sone and Metcalfe, 2008; Metcalfe, 2011; Jian et al., 2009; Peng et al., 2014).

The Changning Menglian suture zone contains magmatic arc and back-arc rock assemblages, an ophiolitic mélange, shallow marine carbonates, and a flysch unit containing Devonian-Triassic radiolarians (Feng and Liu, 1993; Feng and Ye, 1996; Feng and Zhang, 1997). It extends southward to the Inthanon and Bentong Raub suture zones (INS, BRS), which are interpreted to represent the main Paleo-Tethyan Ocean (Metcalfe, 2011). It connects to the north with the E-W-trending Longmu Tso-Shuanghu suture zone in central Tibet (Fig. 1). Deep oceanic sedimentary rocks in this suture zone include radiolarian cherts that range in age from the middle Devonian to the middle Triassic, and Upper Devonian and lower Carboniferous conodont faunas (Sone and Metcalfe, 2008; Metcalfe, 2011).

The Changning-Menglian ophiolite has a suprasubduction zone affinity with a U$\mathrm{Pb}$ zircon age of $292 \mathrm{Ma}$. Another gabbro from this ophiolite has yielded a $\mathrm{U}-\mathrm{Pb}$ zircon age of $267 \mathrm{Ma}$ (Jian et al., 2009). These two ages may represent the early Permian seafloor spreading and younger suprasubduction zone evolution of the ophiolite. This kind of multi-stage evolution of oceanic lithosphere in marginal basins has been well- 
documented from the Neo-Tethyan ophiolites in the Mediterranean region (Dilek et al., 1990; Dilek and Flower, 2003; Dilek et al., 2008; Dilek and Thy, 2009; Uysal et al., 2014). The Mojiang high-P metamorphic belt associated with the Changning Menglian suture zone formed during subduction of the Changning-Menglian branch of PaleoTethys. $\mathrm{Ar}^{40}-\mathrm{Ar}^{39}$ dating of phengite and crossitic amphibole separates from glaucophane schist in Mojiang has yielded cooling ages of 293.9 \pm 0.9 Ma (Liu et al., 1989) and 279 Ma (Liu et al., 1993), respectively.

\subsubsection{Jinghong, Nan-Uttaradit and Sra Kaeo suture zone (JH-NU-SKS)}

The Jinghong, Nan-Uttaradit and Sra Kaeo suture zone runs parallels to the Changning-Menglian, Inthanon and Bentong-Raub suture zones (CM-IN-BRS) on the west side of the Simao-Indochina terrane. The Jinghong, Nan-Uttaradit and Sra Kaeo suture zones contain volcanic rocks, mélanges, and ophiolites, which represent a Permian back-arc basin that closed in the middle Triassic (Sone and Metcalfe, 2008; Metcalfe, 2011). The Jinghong granodioritic pluton in the eastern Lincang batholith has yielded U-Pb zircon ages of 284-282 $\mathrm{Ma}, \varepsilon_{(\mathrm{Nd})}$ values of -3.1 to -3.6 , and initial $\mathrm{Sr}$ isotopic ratios of $0.709-0.710$. Its geochemical and isotopic signatures are characteristic of back-arc magmas (Hennig et al., 2009).

\subsubsection{Lincang-Sukhothai-Chanthaburi arc terrane}

The N-S-trending Lincang arc terrane on the eastern side of the Changning Menglian suture zone lies between the Sibumasu and Indochina terranes (Fig. 3; Henning et al., 2009). Previous studies have shown that the Lincang arc terrane is composed of a granitic batholith and a volcanic-sedimentary sequence. The available ages for the Lincang granites range between $282 \mathrm{Ma}$ and $275 \mathrm{Ma}$ Liu et al. (1989). The whole-rock Rb-Sr ages reported by Chen (1987) show a peak distribution around 297279 Ma. However, Peng et al. (2006 a, b) have reported ${ }^{206} \mathrm{~Pb} /{ }^{238} \mathrm{U}$ zircon ages of 230229 Ma from the Lincang (LC) granites. Zircon separates from rhyolitic rocks in the northern end of the Lincang terrane have revealed a ${ }^{206} \mathrm{~Pb} /{ }^{238} \mathrm{U}$ age of $231 \mathrm{Ma}$ (Peng et 
al., 2006a, b). It is widely accepted that the Paleo-Tethyan Changning-Menglian oceanic lithosphere was subducted eastward beneath the Lincang-Sukhothai-Chanthaburi terrane in the Permian, and that this Andean-type magmatism produced the Triassic Lincang batholith.

2.3 Jinshajiang-Ailaoshan-Song Ma suture zone and its Paleo-Tethyan subduction system

\subsubsection{Jinshajiang-Ailaoshan-Song Ma suture zone}

\subsubsection{Jinshajiang-Ailaoshan Suture Zone (JSJ-ALS)}

The Jinshajiang-Ailaoshan suture zone occurs between the Songpan Ganze, the North Qiangtang-Qamdo-Simao-Indochina terrane, and the South China block, and curves southward to connect with the Song Ma suture zone (Tran Van Tri, 1979; Hutchison, 1989; Lepvrier et al., 2008). It is inferred that the Jinshajiang-Ailaoshan suture zone marks a closed branch of the main Paleo-Tethyan Ocean.

The Jinshajiang suture zone lies in the northern segment of the JinshajiangAilaoshan-Song Ma suture zone, and is subdivided into two branches near its center, known as the Litang suture zone in the east and the Batang suture zone in the west. The Litang suture contains meta-peridotites, cumulate rocks, mid-ocean ridge basalts (MORB), a gabbro-dike complex, chert, and deep-sea sedimentary rocks containing exotic blocks. The Batang suture zone contains MORB-type basalt, serpentinized peridotites, cumulate gabbro, doleritic dikes and radiolarian cherts (Zhang and Jin, 1979; Liu et al., 1983; Chen, 1987; Liu et al., 1990; Xu et al., 1992).

The Jinshajiang ophiolite includes a cumulate gabbro-anorthosite unit and an amphibole gabbro with crystallization ages of $338 \mathrm{Ma}$ and 329-320 Ma, respectively. Jian (2008) has interpreted this ophiolite as a remnant of oceanic crust that developed in an ocean-continent transition (OCT) zone lithosphere, analogous to continental margin ophiolites (Dilek and Furnes, 2011, 2014). This ocean-continent transition zone formed in the late Devonian, during the initial rift-drift stages of the tectonic evolution of the Jinshajiang basin in Paleo-Tethys.

An ophiolitic isotropic gabbro dated at 282-285 Ma, a granite dated at $268 \mathrm{Ma}$ and 
a gabbro with a crystallization age of $264 \mathrm{Ma}$ in an ophiolitic mélange constitute a Permian intraoceanic arc complex at the southern end of the Jinshajiang suture zone (Jian et al., 2008). The Shusong and Xuitui plagiogranites, dated at $340 \mathrm{Ma}$ and $294 \mathrm{Ma}$, respectively, are part of an ophiolite massif in the Jinshajiang suture zone (Wang et al. 2000). Based on these data, we deduce that that the Jinshajiang branch of Paleo-Tethys was initially formed in the Devonian. The three pre-orogenic (before T3 collision) granitoid intrusions (Zhu et al., 2011) were emplaced along the Jinshajiang suture zone at $234-231 \mathrm{Ma}$.

Newly obtained data from the Central Ailaoshan ophiolite (CAO) indicate its igneous ages of late Devonian-early Carboniferous ( 380-330 Ma). U-Pb zircon dating of two granitic plutons along the Ailaoshan suture zone has yielded the ages of $\sim 252$ $248 \mathrm{Ma}$, indicating that calc-alkaline magmatism represented by these plutons occurred in the latest Permian and early Triassic (Liu et al., 2014).

\subsubsection{Song Ma Suture Zone}

The Song Ma suture zone (SMS) has been considered by many scientists as the boundary between the South China and Indochina blocks that was created by the closure of Paleo-Tethys (Tran, 1979; Lepvrier et al., 2004). An ophiolite along the Song Ma suture zone is composed of serpentinized peridotites, high-Al chromitites, gabbro, basaltic lavas, mafic dikes, and chert. The metabasaltic rocks and gabbros in the ophiolite and the spatially associated eclogitic rocks all exhibit MORB-type geochemical affinities (Findlay and Phan, 1997; Lepvrier et al., 1997, 2004; Lacassin et al., 1998; Trung et al., 2006).

High-grade metamorphic rocks, including granulites and eclogites, have been reported from the Song Ma suture zone (Nakano et al., 2004, 2007; Osanai et al., 2004; Zhang et al., 2012). The P-T conditions of formation of the gneissic rocks are calculated as 1.9-2.0 $\mathrm{GPa}$ and $910-930^{\circ} \mathrm{C}$. U-Pb zircon dating of pelitic gneisses surrounding a granulite block along the Song Ma suture zone has yielded an age of $233 \mathrm{Ma}$ (Nakano et al., 2010). These data collectively show that the granulite facies metamorphism along the Song Ma suture zone occurred in the Carnian (early-Late Triassic). 
A detailed study of an eclogite from the Song Ma suture zone has revealed the peak P-T conditions of $700^{\circ} \mathrm{C}$ and $\sim 2.6 \mathrm{GPa}$. The oceanic protolith of this eclogite appears to have subducted to a mantle depth of $\sim 85 \mathrm{~km}$ (Zhang et al., 2012). U-Pb SHRIMP dating of zircon from this eclogite has yielded an age of $230 \mathrm{Ma}$, which constrains the timing of westward subduction and the closure of a Paleo-Tethyan oceanic basin between the South China and Indo-China blocks as the Carnian (early-late Triassic)

\subsubsection{Yidun Arc terrane related to the Jinshajiang oceanic subduction}

The Yidun arc is part of a Triassic volcanic arc terrane bounded on the east by the Litang suture zone, and on the west by the Jinshajiang suture zone. This arc terrane consists mainly of volcanic rocks, intermediate to felsic intrusions, and flysch sequences (Xu et al., 1992), and is divided into six tectonostratigraphic units. These units are, from west to east: (a) Jinshajiang subduction-accretion complex, including an ophiolitic mélange, a flysch sequence, an accretionary prism complex; (b) Zhongza thrust sheet composed of Paleozoic, low-grade meta-sedimentary rocks; (c) a 244-217 Ma magmatic complex in the west (Reid et al., 2007); (d) central Yidun accretionary complex, composed of lower-middle Triassic to early upper Triassic flysch with numerous exotic blocks of limestone, sandstone and conglomerate; (e) a 215-225 Ma magmatic complex in the east (Reid et al., 2007); and (f) Gangze-Litang subduction complex (Fig. 4A).

\subsubsection{Songpan Ganze accretionary complex}

The Triassic Songpan Ganze basin is a triangular-shaped depocenter, filled with up to $10 \mathrm{~km}$ of sedimentary rocks, described in the literature as the Xikang Formation in the east and the Bayan Har Formation in the west. The Songpan Ganze flysch unit comprises vast accumulations of middle-upper Triassic marine gravity flow deposits, which were intruded by widespread dikes and plutons.

The Triassic sedimentary rocks of the Songpan Ganze terrane are composed of deep-sea clastic rock sequences with turbiditic textures. Abundant blocks of Carboniferous-Permian limestones crop out in the lower part of this sequence. The REE 
geochemistry of the sedimentary rocks is consistent with derivation of their clastic material from an active continental margin and oceanic islands. Paleocurrent measurements in the Triassic flysch indicate transport directions from the north (East Kunlun), east (South China Block) and northwest. We infer that the oceanic lithosphere of the Paleo-Tethyan Jinshajiang basin was subducted northward, leading to the formation of a large-scale Triassic Songpan Ganze accretionary wedge, constructed between the East Kunlun, South China Block, and North Qiangtang-Qamdo-SimaoIndochina terranes. The nearly E-W-trending narrow strip represented by the Bayan Har region is composed of deep-sea turbidites with slump structures. The lower part of the Bayan Har Formation also contains numerous limestone blocks. Clastic material for the Bayan Har flysch was derived from the East Kunlun terrane to the north, as inferred from paleocurrent directions (Xu et al., 1992; She et al., 2006).

Intensely deformed, Triassic deep marine sedimentary rocks are interpreted as the trench fill of a diachronously closing, remnant ocean basin (Nie et al., 1994; Ingersoll et al., 1995; Zhou and Graham, 1996). This tectonic scenario is analogous to the proposed mechanisms for the closure of various Tethyan seaways in the eastern Mediterranean region (e.g. Mediterranean-style closure; Dilek et al., 1990; Dilek et al., 1999; Dilek and Flower, 2003; Dilek et al., 2008; Pullen et al., 2011).

\subsection{East Kunlun-A'nyemaqen suture zone and its Paleo-Tethyan subduction system 2.4.1 East Kunlun-A'nyemaqen suture zone (EKL-ANMQS)}

The nearly 1600-km-long, E-W-trending East Kunlun-A'nyemaqen suture zone separates the East Kunlun and Songpan Ganze terranes in northern Tibet. It extends westward across the Altyn Tagh fault to link with the West Kunlun suture zone (WKLS), which marks the boundary between the West Kunlun (WKL) and Tianshuhai (TSH) terranes. In the Dur'ngoi-Buqingshan area, the East Kunlun-A'nyemaqen suture zone contains a complete suite of ophiolitic rocks, including deformed dunite and harzburgite, cumulate mafic and ultramafic rocks, doleritic dikes, and basaltic lavas. SHRIMP U-Pb dating of zircon grains from the mafic rocks has yielded an age of $308 \mathrm{Ma}$ (Yang et al., 1996). We infer that the East Kunlun-A'nyemaqen strand of Paleo-Tethys began to open 
in the Carboniferous. Northward subduction of its oceanic lithosphere beneath the East Kunlun-Qaidam-Qilian terranes led to the formation of the Bulhanbuda magmatic arc at 270-185 Ma (Xiong et al., 2014) and of the west Qinling accretionary wedge at the active continental margin of the northern A'nyemaqen terrane (Fig. 4B; Yan et al., 2012). The accretionary complex comprises ophiolitic rocks of dunite, cumulate rocks, basaltic lavas, doleritic dikes, radiolarian chert with blocks of Carboniferous-Permian limestones, island arc volcanic rocks, and Precambrian metamorphic units.

\subsubsection{Bulhanbuda arc terrane related to subduction of the East Kunlun-A'nyemaqen} basin of Paleo-Tethys

The Bulhanbuda arc terrane (BAT) and the West Qinling accretionary wedge (WQLAW) are both associated with the A'nyemaqen suture zone. Thrust faults with topto-the-south direction of tectonic transport crop out at the frontal margin of the A'nyemaqen subduction-accretion complex (Fig. 5). A tectonic slice of Paleozoic amphibolite occurs in the central part of the complex. There is a detachment surface between the middle and lower Triassic flysch units, which were deposited in a backarc basin developed above a north-dipping subduction zone.

The Bulhanbuda arc terrane contains widespread, late Permian-late Triassic granitoid plutons and volcanic sequences (Harris et al. 1988; Mock et al. 1999; Mo et al., 2007; Xu et al., 2007). All of these arc rocks are characterized by low $\mathrm{K}_{2} \mathrm{O} / \mathrm{Na}_{2} \mathrm{O}$ ratios (0.35-O.87), high Mg\# (37-55), significant depletion of HFSE (high field strength elements), and enrichment in $\mathrm{Rb}, \mathrm{Ba}$ and $\mathrm{K}$. The granitic magmatism appears to have lasted from $270 \mathrm{Ma}$ to $185 \mathrm{Ma}$, with peak ages around $252 \mathrm{Ma}, 240 \mathrm{Ma}$ and $226 \mathrm{Ma}$ (Chai et al., 1984; Xu et al., 1990; Ma et al., 2011), whereas volcanism seems to have taken place in two stages, i.e., late Permian to early Triassic (262-240 Ma) and late Triassic (230-210 Ma). In general, the late Permian - early Triassic granitoids occur mainly in the southern part of the terrane, whereas the middle Triassic - early Jurassic granitoids largely crop out in the northern part (Fig. 5).

Following the emplacement of the late Permian-early Triassic granitoids and construction of the arc complex, the A'nyemaqen basin within Paleo-Tethys closed in the 
Middle Triassic leading to an arc-continent collision. Post-collisional magmatism, facilitated by slab break-off, produced high-silica adakitic granitoids (230-185 Ma, e.g., Xiong et al., 2014), and was accompanied by focused extensional deformation and sedimentary basin development within the East Kunlun ocean basin. The overthickened orogenic crust also underwent partial melting, producing S-type granites.

\subsubsection{West Qinling accretionary wedge related to subduction of the A'nyemaqen basin}

The triangular-shaped West Qinling accretionary complex is bounded by the Zhongwulong ophiolite belt in the northeast and by the A'nyemaqen ophiolite in the south. The Zhongwulong ophiolite consists of upper mantle peridotites, gabbros, doleritic dikes, chert and basaltic pillow lavas. Mafic dikes from this ophiolite have revealed $\mathrm{Rb}$-Sr isochron ages of 318 $\pm 3 \mathrm{Ma}$ (Wang et al., 2001). A gabbro sample from the Zhongwulong ophiolite dated by the LA-ICP-MS U-Pb zircon method has yielded an age of $250 \mathrm{Ma}$ (Wang et al., 2007), and calc-alkaline volcanic rocks from the southern side of the accretionary complex have yielded ages ranging from $246 \mathrm{Ma}$ to $238 \mathrm{Ma}$ (Fig. 6) (Zhang et al., 2007; Guo et al., 2009). The Triassic West Qinling accretionary complex developed as a result of northward subduction of the oceanic lithosphere of the E-W-trending, East Kunlun-A'nyemaqen basin within Paleo-Tethys (Jiang et al., 1996).

\subsection{Sumdo suture zone and its Paleo-Tethyan subduction system}

\subsubsection{Sumdo Suture zone (SDS)}

The Carboniferous-Permian Sumdo suture zone lies in the central Lhasa terrane, where it separates the South Qiangtang-North Lhasa terrane from the South Lhasa terrane (Bureau of Xizang Geological and Resources Survey, 1993; Yang et al., 2007). It is marked by ophiolites and an E-W- trending, nearly 100-km-long Sumdo eclogite belt (Fig. 7), which occurs as tectonic slices in a garnet-bearing, mica-quartz schist and amphibolites (Yang et al, 2006). The protolith of these metamorphic rocks was a flysch sequence, which is known as the Sumdo Formation.

Pressure-temperature calculations of the eclogitic rocks have yielded peak 
metamorphic conditions of $2.7 \mathrm{GPa}$ and $730^{\circ} \mathrm{C}$, close to the phase boundary between coesite and quartz. Geochemical data suggest that protolith of the eclogitic rocks was mid-ocean ridge basalt (MORB), derived from the depleted upper mantle of PaleoTethys (Yang et al., 2006; Chen et al., 2009, 2010). U-Pb SHRIMP dating of zircon separates from the eclogitic rocks has yielded an average metamorphic age of $262 \pm 5 \mathrm{Ma}$, which is interpreted to reflect the timing of Paleo-Tethyan oceanic subduction.

Amphibolite-facies metamorphic rocks at Nyainqentanglha consist mainly of gneiss, amphibolite, quartz schist and marble, and occur as blocks in the western Sumdo high-P metamorphic complex. Metamorphic zircons from the Nyainqentanglha amphibolite, which was produced by retrograde metamorphism of the Sumdo eclogite in the Triassic, have yielded concordant ${ }^{206} \mathrm{~Pb} /{ }^{238} \mathrm{U}$ ages of $225-213 \mathrm{Ma}$ (Dong et al., 2011). These rocks, together with the eclogitic units, represent a nearly 300-km-long, E-Wtrending, Permo-Triassic metamorphic belt.

Muscovite separates from muscovite-quartzite schist in the Sumdo Formation have yielded ${ }^{40} \mathrm{Ar} /{ }^{39} \mathrm{Ar}$ cooling ages of $240-220 \mathrm{Ma}$, similar to the ages obtained from muscovite and amphibole separates from the eclogite belt (240-220 Ma) (Li et al., 2009). We interpret these ages to mark the timing of the orogenic deformation and metamorphism.

\subsubsection{Sumdo Paleo-Tethyan accretionary wedge}

Structures within the Sumdo Formation include E-W-striking, ductile thrust faults with top-to-the-north sense of shearing, south-dipping foliation planes, 'A'-type folds and mylonitic textures ( $\mathrm{Li}$ et al., 2009). Brittle thrust faults with top-to-the-south sense of shearing are superimposed on these previously formed ductile structures (Fig. 7). Granitic plutons that are 240-190 Ma in age are intrusive into various metamorphic units of the Sumdo Formation.

Medium-pressure amphibolites formed in the western segment of the Sumdo high-P metamorphic complex in the Norian (225-213 Ma; Dong et al., 2011), followed by the formation of high-T metamorphic rocks in the eastern segment during the latest Triassicearly Jurassic ( 204-192 Ma; Lin et al., 2013). The Sumdo accretionary complex makes 
up a 300-km-long and 50-km-wide zone in the eastern part of the Central Lhasa terrane that developed during a late Triassic, collisional orogen. Syn- to post-collisional granites (223-190 Ma) are intrusive into this accretionary complex (Li et al., 2009).

\section{Paleo-Tethys system and collisional orogens of the passive margins of the Yangtze block}

Orogenic deformation during plate collisions is not limited to narrow plate boundaries, and may extend into plate interiors, far from collision fronts. Amalgamation of multiple continental blocks within an oceanic realm, such as in the Melanesian region in the SW Pacific Ocean, may lead to construction of an orogenic collage with widths of hundreds or even thousands of kilometers. The Paleo-Tethyan mountain belt in Tibet is a good example of such an orogenic collage, extending nearly $5200 \mathrm{~km}$ along its E-W length and $2500 \mathrm{~km}$ across its N-S width, and it is thus an excellent natural laboratory to study the processes of an accretionary orogen buildup (Xu et al., 2007, 2012, 2013). The Paleo-Tethyan mountain belt in Tibet that formed during the collision of the East Cimmerides and the West Cathaysides is connected in the east with the Qinling-DabieSulu-Ogcheon orogenic belts between the North and South China blocks.

\subsection{Paleo-Tethyan system on the western margin of the Yangtze block}

The Jinshajiang-Ailaoshan-Song Ma suture zone occurs between the North Qiangtang-Simao-Indochina terrane, South China block, and the Songpan Ganze terrane. Studies have shown that the Jinshajiang-Ailaoshan-Song Ma Paleo-Tethyan oceanic slab was subducted westward beneath the North Qiangtang-Simao-Indochina terrane along the Jinshajiang and Ailaoshan-Song Ma trenches, producing the Yidun and Song Ma arc terranes.

The Emeishan large igneous province, located in the SW margin of the South China block, comprises a bimodal mafic-silicic suite with the silicic rocks occurring in the uppermost part of a thick lava sequence. The silicic rocks have ages of 257-263 Ma, and display rather uniform $\varepsilon_{(\mathrm{Nd})}$ values $(+1$ to +2.9$)$ that are comparable with those of 
uncontaminated, high-Ti basalts (Xu et al., 2010). The geochemistry of these bimodal lavas reveals that at least two different mantle source components were involved in their melt evolution: an enriched mantle and a depleted mantle.

We infer a subduction model for the Jinshajiang-Ailaoshan Paleo-Tethyan slab in a 'trench-ridge-trench' triple junction configuration. Regional studies show that the Jinshajiang-Ailaoshan-Song Ma Paleo-Tethyan oceanic slab was subducted westward beneath the North Qiangtang-Simao-Indochina terrane along the Jinshajiang-Ailaoshan trenches, along with a Permian Emeishan basaltic buildup on the western margin of the Yangtze block. The South China block included the South Qinling terrane along its northern margin and the Songpan-Ganze terrane on its northwestern margin prior to the collision between the South China block, North China block, and Indochina terranes. The passive margins of the South China block were involved in the Triassic collisional events that developed decollement-type orogens (Fig. 8).

3.2 Decollement-type orogens of the northern and northwestern margins of the South China block

3.2.1 Decollement orogen in the Songpan Ganze terrane, NW margin of the South China block

The Songpan Ganze terrane is a triangular-shaped, Paleo-Tethyan collisional orogen, which is separated from the East Kunlun terrane to the north by the A'nyemaqen suture zone, from the South China Block to the east by the Longmenshan thrust fault, and from the North Qiangtang terrane to the southwest by the Jinshajiang suture zone. It is composed of a Neo-Proterozoic basement and Paleozoic cover sequences, which include Sinian volcanic meta-conglomerate, sandstone, marble, quartzite and quartz-schist, Ordovician marble and limestone interlayered with quartzite and mica-schist, Silurian limestone, Devonian dolomite and limestone interlayered with phyllite, Carboniferous limestone, and Permian basalt interlayered with carbonates in the eastern part of the Songpan Ganze terrane.

The eastern Songpan Ganze terrane is characterized by widespread magmatic rocks, which formed above two separate subduction zones during the mid to late Triassic. 
These two subduction systems led to the closure of Paleo-Tethys and to the development of the Kunlun-A'nyemaqen suture to the north and the Jinsha-Litang suture to the south.

Plutons in the western Songpan Ganze terrane have yielded U-Pb zircon ages ranging from 225 to $193 \mathrm{Ma} .{ }^{40} \mathrm{Ar} /{ }^{39} \mathrm{Ar}$ analyses of muscovite separates from the Hudongliang and Zhuonai Lake plutons have yielded the ages of $210.7 \pm 2.5 \mathrm{Ma}$ and $212.7 \pm 2.5 \mathrm{Ma}$, respectively. These plutonic rocks can be subdivided into two distinct geochemical groups: the 221-212 Ma plutons are composed of high-K, calc-alkaline granitoids that were likely derived from partial melting of the downgoing Paleo-Tethyan oceanic slab and its overlying marine sediments (Zhang et al., 2014). The 225-193 Ma plutons (Daheishan, Yunwuling, Zhuonai Lake, Malanshan and Hudongliang) were produced by partial melting of juvenile crust. Collectively, these data suggest that the Hoh-Xil turbiditic sequences of the Songpan Ganze basin are underlain by continental arc crust, which is more widespread than previously thought.

A large-scale, south-verging, décollement zone separates the Neo-Proterozoic basement in the Yangtze block from the Sinian-Triassic cover sequences in the eastern Songpan Ganze terrane (Malavielle et al., 1991; Mattauer et al., 1992; Xu et al., 1992; Calassou, 1994; Roger et al., 2004; Harroufield and Wilson, 2005). This décollement zone is about $2-3 \mathrm{~km}$ thick, and is characterized by a shear zone with a well-developed mylonitic foliation and a nearly N-S trending stretching lineation. Foliation planes are steeply dipping higher up in the upper parts of the cover sequences and subhorizontal to gently dipping in the lower Sinian-Triassic sequences below. The high temperature $\left(>650^{\circ} \mathrm{C}\right)$ fabric and numerous granitic veins within the shear zone developed as a result of the south-vergent, thick-skinned thrust faulting and folding during the Indosinian Orogeny ( 230-200 Ma). This deformation led to crustal thickening and shortening of the Songpan Ganze terrane. Barrovian-type metamorphic mineral assemblages characterized by sillimanite $\left(T>600-700^{\circ} \mathrm{C}\right)$, kyanite-staurolite $\left(\mathrm{T}=550^{\circ}\right.$ $\left.570^{\circ} \mathrm{C}\right)$, Fe-Al-bearing garnet $\left(\mathrm{T}=500^{\circ}-540^{\circ} \mathrm{C}\right)$, and biotite $\left(\mathrm{T}=400^{\circ}-500^{\circ} \mathrm{C}\right)$ are associated with the shear zone fabrics, indicating crustal depths of $>15-20 \mathrm{~km}$ for their origin around 220-190 Ma (Xu et al., 1992; Huang et al., 2003; Zhou et al., 2008).

Partial melting of the overthickened orogenic crust produced syn-collisional, Itype granitic intrusions with ages of 225-190 Ma (Xu et al., 1992; Roger et al., 1995, 
1997, 2004; Zhang et al., 2006, 2007; Reid et al., 2007; Xiao et al., 2007; Weislogel, 2008), and post-collisional, S-type granites with ages of 200-150 Ma and 153-105 Ma (Roger et al., 2004; Reid et al., 2007). Along the southern front of the décollement, the basement rocks were uplifted and thrust onto the Paleozoic sedimentary strata. Subsequent N-S-oriented crustal contraction migrated from the north to south, and produced localized deformation associated with refolding of the Danba and Muli antiforms (Fig. 9).

Similar to the South Qinling orogenic belt, the east Songpan Ganze is a Triassic décollement orogen with top-to-the-south sense of shearing (Fig. 10; Xu et al., 1986, 1992, 2012, 2013). The only significant difference between the two is that the Songpan Ganze terrane represents a high-temperature collisional orogen, whereas the South Qinling orogenic belt is mainly a low-temperature mountain belt.

\subsubsection{Décollement orogen in the South Qinling terrane along the northern margin of the} South China block

The South Qinling orogenic belt is bounded by the Proto-Tethyan Danfen suture zone in the north and the curvilinear Daba foreland thrust belt in the south. It includes a large-scale, décollement shear zone between the Neo-Proterozoic basement and the Sinian-Triassic cover (Fig. 10).

A well-developed, mylonitic foliation, $\sim \mathrm{N}$-S-trending stretching lineation and sheath folds are observed in the top part of the Precambrian basement. Microstructures and quartz lattice-preffered orientations (LOPs) in the mylonitic rocks indicate top-tothe-south sense of shearing under low temperatures $\left(<400-450^{\circ} \mathrm{C}\right)$. Structures in the Sinian to Lower-Middle Triassic cover sequence are characterized by recumbent to gentle folds dipping to the north and upright folds that dip steeply to the north. Phengite separates from medium-pressure amphibolitic rocks in the décollement zone have revealed an ${ }^{40} \mathrm{Ar}-\rho^{39} \mathrm{Ar}$ cooling age of $232 \mathrm{Ma}$, whereas Na-feldspar grains from the same sequence have yielded an age of $216 \mathrm{Ma}(\mathrm{Xu}, 1987 \mathrm{a}, \mathrm{b})$.

\section{Discussion}




\subsection{Tectonic framework of the East Cimmerides and West Cathaysides in Tibet}

The Paleo-Tethyan tectonics in Tibet involves the formation of ophiolites and ophiolitic mélanges, island arc and magmatic arc complexes, high-pressure metamorphic belts, and accretionary wedges containing numerous exotic blocks. These units mark suture zones, which separate Gondwana-derived terranes that were accreted into Asia during the late Paleozoic and Mesozoic (e.g. Carter et al., 2001; Metcalfe, 2002, 2006, 2011, 2013). The Devonian Longmu Tso-Shuanghu-Changning Menglian suture zone is the main boundary between the West Cimmerides and East Cathaysides; the other suture zones represent the closure sites of marginal basins within Paleo-Tethys (Lepvrier et al., 2008).

The East Cimmerides and the West Cathaysides in Tibet contain six major terranes, including East Kunlun, Songpan Ganze, North Qiangtang-Qamdo-Simao-Indochina, South Qiangtang-Baoshan-Sibumasu, North Lhasa-Tengchong and South Lhasa. There are five ophiolite belts (East Kunlun-A'nyemaqen, Ganze-Litang, JinshajiangAilaoshan-Song Ma, Longmu Tso/Shuanghu-Changning/Menglian and Jinghong) associated with the major suture zones and five volcanic arcs (Bulhanbuda, Yidun, Longmu Tso- Shuanghu, Lincang-Sukhothai and Sumdo). In addition, there are four accretionary wedges (West Qinling, Bayan Har-Songpan Ganze, Shuanghu-NierongJitang and Sumdo), and four high-P metamorphic belts (Song Ma, Longmu TsoShuanghu, Mojiang and Sumdo).

The subduction polarities of the multiple Paleo-Tethyan oceanic slabs differed during the late Paleozoic-Early Triassic evolution of Paleo-Tethys. We can infer the subduction polarities based on the kinematics of structures preserved within deformed rocks associated with the suture zones, the orientations of paired metamorphic zones in the orogenic belts, and the occurrence and geochemistry of volcanic rocks on either side of the ophiolitic belts.

The E-W-trending East Kunlun-A'nyemaqen oceanic slab was subducted northward beneath the East Kunlun terrane in northern Tibet, whereas the Sumdo oceanic slab was subducted northward beneath the North Lhasa terrane in southern Tibet. The Longmu Tso Shuanghu-Changning Menglian ophiolites indicate eastward 
subduction of a Paleo-Tethyan oceanic slab beneath the North Qiangtang-QamdoSimao-Indochina terrane in central Tibet.

The southern Jinshajiang-Ailaoshan-Song Ma oceanic slab may have been subducted westward beneath the North Qiangtang-Qamdo-Simao-Indochina terrane. However, the tectonic setting of the Yidun arc in the central Jinshajiang-AilaoshanSong Ma suture zone and the related structural evidence suggest that subduction along the Jinshajiang component of this suture zone was to the east. Subduction along the Ganze-Litang suture zone was, on the other hand, apparently to the west. The subduction polarity on the Jinshajiang suture zone has been interpreted differently by different authors. Xu et al. (1992) and Mo et al. (1994) proposed eastward subduction, whereas Reid et al. (2005a, b) argued for west-dipping subduction. Therefore, the relationship between the observed structures and the subduction polarities across the Yidun arc are still unresolved, and have been interpreted differently in models of the Ganze-Litang and Jingshajiang suture zones.

\subsection{Genesis of the Longmu Tso Shuanghu-Changning Menglian mélange}

Two different interpretations have been presented for the formation of the Longmu Tso-Shuanghu mélange: an in-situ or autochthonous model and an allochthonous model. The in-situ model is based on reports that the E-W-trending Longmu Tso-Shuanghu suture zone, which contains high-P metamorphic rocks and an ophiolitic mélange, separates the Upper Paleozoic strata containing warm-water fauna of a Cathaysian affinity in the north Qiangtang terrane from the strata in the south that contain coldwater fauna of a Gondwana affinity (Li et al., 2005, 2006; Zhai et al., 2011a, b). The NS-trending Changning-Menglian suture zone, which is the southern segment of the Longmu Tso-Shuanghu-Changning Menglian suture zone, also contains an ophiolitic mélange, magmatic arc rocks, backarc-basin deposits, and a deep-sea flysch unit. The flysch in this zone contains Devonian-Triassic radiolarians (Feng and Liu, 1993; Feng and Ye, 1996; Feng and Zhang, 1997). These sutures clearly represent important terrane boundaries as inferred from the occurrence of highly different Carboniferous-Permian sedimentary sequences and faunal successions on their opposite sides (Metcalfe, 2002; 
Sone and Metcalfe, 2008; Matcalfe, 2011; Zhang et al., 2013).

The allochthonous model suggests that the Longmu Tso-Shuanghu mélange was underplated southward beneath the Qiangtang terrane during the early Mesozoic by flat subduction of the Songpan Ganze oceanic lithosphere (Kapp et al., 2000; Pullen et al., 2011). The Longmu Tso-Shuanghu mélange is distributed for $\sim 200 \mathrm{~km}$ along the Jinshajiang suture zone and includes metamorphic mineral assemblages indicating P-T conditions of their formation around $60-80 \mathrm{~km}$ at depth in a subduction zone (Zhai et al., 2011b). We find this evidence incompatible with a flat subduction interpretation, and hence favor the autochthonous model.

\subsection{Interpretation of the Paleo-Tethyan Sumdo suture zone in southern Tibet}

Permian marine deposits in Tibet crop out in an array of blocks where they contain diverse faunas of diverse biogeographical affinities. The North Qiangtang-Qamdo terrane contains Permian marine fauna of a typical Cathaysian affinity, whereas the Himalayan stratigraphic units are characterized primarily by cold-water faunas with only limited warm-water immigrants. The intervening South Qiangtang and Lhasa terranes are ascribed to the Cimmerian, which is characterized by mixed warm- and cold-water fauna, supplemented by a strong endemic component (Zhang et al., 2013). Thus, we suggest that the South Qiangtang and Lhasa terranes constituted a single block before the opening of the Bangonghu-Nujiang strand of the Neo-Tethyan Ocean.

The Sumdo suture zone, which is composed of ophiolites, high-P eclogites, arc volcanic rocks, and an accretionary wedge complex, is a newly discovered PaleoTethyan suture in the South Qiangtang-Lhasa terrane (Yang et al., 1998). The oceanic lithosphere of the Sumdo branch of Paleo-Tethys was subducted northward beneath the North Lhasa terrane prior to the development of this suture zone.

\subsection{Tectonic model for the evolution of Paleo-Tethyan and Triassic orogens in Tibet}

The main stages of the tectonic evolution of Paleo-Tethys and of the PaleozoicTriassic orogenic belts are depicted in Figure $\mathbf{1 1}$ and are summarized below. 
(1) Opening of Paleo-Tethys: Paleo-Tethys was initially opened in the DevonianCarboniferous, leading to the formation of continental margin and MOR-type of oceanic lithosphere (Dilek and Furnes, 2011, 2014). The remnants of these lithospheric types are preserved in the Longmu Tso Shuanghu-Changning Menglian ophiolite belt between the East Cimmerides and the West Cathaysides. The Jinshajiang-Changning Menglian ( 380-330 Ma), East Kunlun-A'nyemaqen ( 308 Ma) and Sumdo ophiolites ( $305 \mathrm{Ma})$ represent the remnants of various strands of the main Paleo-Tethyan Ocean between the East Kunlun and Songpan Ganze terranes, the Songpan Ganze and North QiangtangQamdo-Simao-Indochina terranes, and the South Qiangtang/Lhasa-Tengchong/BaoshanSibumasu terranes, respectively.

(2) Early subduction stage of Paleo-Tethyan oceanic slabs: The oceanic lithosphere of the East Kunlun-A'nyemaqen basin was subducted northward beneath the East Kunlun terrane, forming the Bulhanbuda arc terrane in northern Tibet around 270-185 Ma. The Sumdo oceanic slab was subducted northward beneath the North Lhasa-South Qiangtang terrane, developing a Carboniferous-Permian volcanic arc in southern Tibet.

In Southeast Tibet, the oceanic lithosphere of the Changning Menglian branch of Paleo-Tethys was subducted eastward beneath the Indochina terrane, producing the Mojiang high-P metamorphic belt (294 Ma) and the Lincang arc terrane (Fig. 11B). Formation of this arc terrane overlapped with seafloor spreading in the Jinghong backarc basin (282-264 Ma). The Jinshajiang-Ailaoshan-Song Ma oceanic slab was then subducted westward beneath the Qamdo-Simao-Indochina terrane. Meanwhile, the Emeishan bimodal, mafic-silicic volcanic suite developed along the western rifted margin of the South China block during the late Permian (257-263 Ma). The Emeishan magmatic event is considered to have emanated from a deep mantle plume that produced widespread volcanic rocks (Fig. 11B).

In Central Tibet, the ocean floor of the Longmu Tso Shuanghu branch of PaleoTethys was subducted northward beneath the North Qiangtang terrane. This subduction process produced a magmatic arc during 275-248 Ma.

(3) Late subduction stage of Paleo-Tethyan oceanic slabs: Subduction of Paleo-Tethyan 
oceanic slabs continued in the Triassic, as recorded in the West Qinling accretionary wedge, the Yidun arc (227-218 Ma), the Longmu Tso-Shuanghu arc terrane (220-205 Ma) and the high-P metamorphic belts of the Longmu Tso Shuanghu (244-238 Ma) and Song Ma (232Ma) suture zones. The Mojiang and Sumdo high-Pressure metamorphic zones were formed during an early subduction stage and were then exhumed to shallow depths in a subduction channel. The Jinghong back-arc basin was closed in the Middle Triassic, leading to an arc-continent collision (Fig. 11C).

(4) Final closure of Paleo-Tethys and terrane amalgamation: Closure of the multiple branches of the Paleo-Tethyan Ocean resulted in terrane amalgamation and development of a large orogenic collage in Tibet during the latest Triassic-Jurassic. The geological record of this collage reflects the rift-drift, seafloor spreading, subduction zone, and collision tectonics of the Paleo-Tethyan realm and the continental blocks within and around this Pacific-type, complex oceanic domain.

\section{Conclusions}

The Paleo-Tethyan geology of Tibet involves multiple terranes, suture zones containing ophiolites and ophiolitic mélanges, high-P metamorphic belts, magmatic arcs, and accretionary prism complexes that largely developed during the Paleozoic-early Mesozoic. This Paleo-Tethyan realm is subdivided into two main domains based on the existence of diverse Permian sedimentary sequences and faunal successions: the East Cimmarides to the west and the West Cathaysides to the east. The Devonian Longmu Tso Shuanghu-Changning Menglian suture zone separates these two main domains. The other suture zones in Tibet represent the sites of closure of the multiple strands of the main Paleo Tethyan Ocean.

Subducting Paleo-Tethyan oceanic slabs had different polarities during the late Paleozoic-early Triassic evolution of this ocean, which had a complex paleogeography. The East Kunlun-A'nyemaqen oceanic slab was subducted northward beneath the East Kunlun terrane in northern Tibet, whereas the Sumdo oceanic slab was subducted northward beneath the South Qiangtang-North Lhasa terrane in southern Tibet. The 
structural architecture and the geochemical fingerprints of the Longmu Tso ShuanghuChangning Menglian and Jinshajiang-Ailaoshan-Song Ma ophiolite belts indicate that Paleo-Tethyan oceanic slabs were subducted in opposite directions (westward and eastward) beneath the North Qiangtang-Qamdo-Simao-Indochina terrane in central Tibet. The model for the Jinshajiang-Ailaoshan-Song Ma oceanic slab suggests its westward subduction beneath the North Qiangtang-Simao-Indochina terrane along the Jinshajiang and Ailaoshan-Song Ma trenches in a trench-ridge-trench triple junction configuration. The Permian Emeishan volcanic field marks a zone of discrete volcanism and associated rifting on the western margin of the South China Block that was fed by a mantle plume beneath the Paleo-Tethyan realm.

Multiple collision events between various Paleo-Tethyan terranes in Tibet produced a vast Indosinian orogenic collage during the latest Triassic-Jurassic. This crustal collage has been affected by post-Jurassic to Cenozoic deformation that produced a crustal-scale shear zone and décollement between the Precambrian basement and the cover sequences, regional thrust faults and folds, and strike-slip fault zones.

\section{Acknowledgments}

This study was supported by National Natural Science Foundation of China (No. 40921001, 41221061, 41430212, 41202153, 41472198), the Chinese Geological Survey Project (No.1212010818094, 1212011120161, 12120114078201) and Grants from the Ministry of Land and Resources of China (No. 201211093). Prof. Bor-Ming Jahn (Editor-in-Chief) and two anonymous referees provided thoughtful and constructive reviews that helped us improve the science and organization in the paper. We thank Miao Zhang and Chan Wu for their assistance in digitally constructing the figures in this paper. Y Dilek's research in Tibet has been supported by the Chinese Academy of Geological Sciences. 


\section{References}

Arnaud, N.O., 1992. Apports de la thermochronologie ${ }^{40} \mathrm{Ar} /{ }^{39} \mathrm{Ar}$ sur feldspath potassique a la connaissance de la tectonique cenozoique d'Asie. PhD Dissertation, University of Blaise Pascal.

Brown, M., 2006. Duality of thermal regimes is the distinctive characteristic of plate tectonics since the Neoarchean. Geology 34, 961-964.

Brown, M., 2009. Metamorphic patterns in orogenic systems and the geological record. In: Cawood, P.A. and Kröner, A. (eds), Earth Accretionary Systems in Space and Time. Geological Society, London Special Publications 318, 37-74.

Calassou S., 1994. Etude tectonique d'une chaîne de décollement. (a) Tectonique triasique et tertiaire de lachaîne de Songpan-Garzê. (b) Géométrie et cinématique des deformations dans les prismes d'accrétion sédimentaires: modélisation analogque. PhD thesis. Montpellier: Université Montpellier

Carter, A., Roques, D., Bristow, C., Kinny, P., 2001. Understanding Mesozoic accretion in Southeast Asia: significance of Triassic thermotectonism (Indosinian orogeny) in Vietnam. Geology 29, 211-214.

Cawood, P.A. and Kröner, A. (eds.), 2009a. Earth Accretionary Systems in Space and Time. Geological Society of London Special Publication 318, 1-36.

Cawood, P.A., Kröner, A., Collins, W.J., Kusky, T.M., Mooney, W.D., Windley B.F., 2009b. Accretionary orogens through Earth history. Geological Society of London.

Chai, Y.C., Feng, B.G.,Yang, J.S., 1984. The characteristics and origin of the DongxiDatan granite belt in middle part of the East-Kunlun. Collected Works on Geology in the Tibetan Plateau 15, 78-90 (in Chinese with English abstract).

Chang, C.F., Chen, N.S., Coward, M.P., Deng, W.M., Dewey, J., Gansser, A., Harris, N.B.W., Jin, C.W., Kidd, W.S.F., Leeder, M.Z.R., Li, H., Lin, J.L., Houjun, M., Moner, P., Pan, Y., Pan, Y.S., Pearce, J.A., Shackleton, R.M., Smith, A.B., Sun, Y.Y., Ward, M., Watts, D.R., Xu, J.T., Xu, R.H., Yin, J.X. and Zhang, Y.Q., 1986. Preliminary conclusions of the Royal Society and Academia Sinica 1985 geotraverse of Tibet, Nature, 323 (6088), 501-507.

Charusiri, P., Charusiri, B., Clark, A.H., Farrar, E., Archibald, D., 1993. Granite belts in Thailand: evidence from the ${ }^{40} \mathrm{Ar} /{ }^{39} \mathrm{Ar}$ geochronological and geological syntheses, 
Journal of Southeast Asian Earth Sciences 8, 127-136.

Chen, B.W., Wang, K.Y., Liu J.X., 1987. Geotectonics of the Nujiang-Lancangjiang Jinshajiang region. Geological Publishing House, Beijing, 1-204 (in Chinese with English abstract).

Chen, J.C., 1987. The discussion of chronological division of granites and selection of isotopic ages. Yunnan Geology 6, 101-113 (in Chinese with English abstract).

Chen, S.Y., Yang, J.S., Li, Y., Xu, X.Z., 2009. Ultramafic blocks in the Sumdo Region, Lhasa Block, Eastern Tibet Plateau: An ophiolite unit. Journal of Earth Science 20, 332-347.

Chen, S.Y. 2010. The development of Sumdo suture in the Lhasa block, Tibet. Ph. D.

Dissertation. Beijing: Chinese Academy of Geological Sciences, 10-187 (in Chinese with English abstract)

Collins, A.S., Fitzsimons, I.C.W., Hulscher, B., Razakamanana, T., 2003. Structure of the eastern margin of the East African Orogen in central Madagascar. Precambrian Research 123, 111-133.

Dilek, Y., 2006. Collision tectonics of the Mediterranean region: Causes and consequences. Geological Society of America Special Papers, 409, 1-13.

Dilek, Y., Thy, P., Moores, E.M., Ramsden, T.R., 1990. Tectonic evolution of the Troodos ophiolite within the Tethyan framework. Tectonics, 9, 811-823.

Dilek, Y., Thy, P., Hacker, B., Grundvig, S., 1999. Structure and petrology of Tauride ophiolites and mafic dike intrusions (Turkey): Implications for the Neotethyan ocean. Geological Society of America Bulletin, 111, 1192-1216.

Dilek, Y., Furnes, H., Shallo, M., 2008. Geochemistry of the Jurassic Mirdita Ophiolite (Albania) and the MORB to SSZ evolution of a marginal basin oceanic crust. Lithos, 100, 174-200.

Dilek, Y., Rowland, J.C., 1993. Evolution of a conjugate passive margin pair in Mesozoic southern Turkey. Tectonics, 12, 954-970.

Dilek, Y., Flower, M.F.J., 2003. Arc-trench rollback and forearc accretion: 2. A model template for ophiolites in Albania, Cyprus, and Oman. Geological Society Special Publication, 218, 43-68.

Dilek, Y., Robinson, P.T., 2003. Ophiolites in Earth history: Introduction. Geological 
Society Special Publication, 218, 1-8.

Dilek, Y., Thy, P., 2009. Island arc tholeiite to boninitic melt evolution of the Cretaceous Kizildag (Turkey) ophiolite: Model for multi-stage early arc-forearc magmatism in Tethyan subduction factories. Lithos, 113, 68-87.

Dilek, Y., Furnes, H., 2011. Ophiolite genesis and global tectonics: Geochemical and tectonic fingerprinting of ancient oceanic lithosphere. Geological Society of America Bulletin, 123, 387-411.

Dilek, Y., Furnes, H., 2014. Ophiolites and their origins. Elements, 10, 93-100.

Ding, D.G., Wang, D., Liu, W.X., Sun, S.Q., 1996. The West Kunlun orogeny and basins. Beijing: Geological Publishing House, p143 (in Chinese with English abstract).

Dong, X., Zhang, Z., Liu, F., Wang, W., Yu, F., Shen, K., 2011. Zircon U-Pb geochronology of the Nyainqêntanglha Group from the Lhasa terrane new constraints on the Triassic orogeny of the south Tibet. Journal of Asian Earth Sciences 42, 732-739.

Ernst, W.G., 2005. Alpine and Pacific styles of Phanerozoic mountain building: Subduction-zone petrogenesis of continental crust. Terra Nova 17, 165-188.

Feng, Q., Liu B., 1993. A new Early Devonian radiolarian genus from western Yunnan, Science in China Series. B 36, 242-248 (in Chinese, with English abstract).

Feng, Q., Zhang, Z., 1997. Early Carboniferous radiolarians from West Yunnan. Acta Micropalaeontologica Sinica 14, 79-92 (in Chinese, with English abstract).

Feng, Q.L., Ye, M., 1996. Permian radiolarian sedimentary assemblage and paleoecology in south and southwest China. In: Long Xiangfu (Ed.). Devonian to Triassic Tethys in Western Yunnan, China. China University of Geosciences Press, Wuhan, 106-112.

Findlay, R.H., Phan, T.T., 1997. The structural setting of the Song Ma Region, Vietnam and the Indochina-South China plate boundary problem. Gondwana Research 1, 1133.

Flower, M.F.J., Dilek, Y., 2003. Are-trench rollback and forearc accretion: 1. A collision-induced mantle flow model for Tethyan ophiolites. Geological Society Special Publication, 218, 21-41. 
Fromaget, J. 1934. Observations et reflexions sur la geologie stratigraphique et structuale de L'Indochine. Bulletin Société Geologie 4, 101-164.

Fromaget, J. 1952. Etudes geologiques sur le Nord-Ouest du Tonkin et le Nord du HautLaos. 2ème et 3ème parties. Bulletin Français Service Géologie Indochine 29, 198.

Fromaget, J., 1927. Etudes géologiques sur le nord de l'Indochine centrale. Bulletin Français Service Géologie Indochine 16, 141-164.

Fromaget, J., 1929. Note preliminaire sur a stratigraphie des formations secondaires et sur l'age des mouvements majeurs en Indochine, in: Comptes Rendues, IVe Congres Science du Pacifique, Java.

Gao, S., Zhang, B.R., Li, Z.J., 1990. Geochemical evidence for Proterozoic continental arc and continental margin rift magmatism along the northern margin of the Yangtze Craton, South China. Precambrian Research 47, 205-221.

Guo, A.L., Zhang, G.W., Qiang, J., Sun, Y.G., Li, G., Yao, A.P., 2009. Indosinian Zongwulong orogenic belt on the northeastern margin of the Qinghai-Tibet Plateau. Acta Petrologica Sinica, 25(1), 1-12.

Harris, N.B.W., Xu, R., Lewis, C.L., Jin, C., 1988. Plutonic rocks of the 1985 Tibet Geotraverse, Lahasa to Golmud. Philosophical Transactions of the Royal Society of London. Series A, Mathematical and Physical Sciences 327(1594), 145-168.

Harrowfield, M.J., Wilson, C.J.L., 2005. Indosinian deformation of the Songpan-Garzê fold belt, northeast Tibetan plateau. Journal of Structural Geology 27, 101-117.

Henning, D., Lemamm, B., Frei, D., Beiyatsky, B., Zhao, X.F., Cabral, A.R., Zeng, P., S., Zhou, M.F., Schmidt, K., 2009. Early Permian seafloor to continental arc magmatism in the eastern Paleo-Tethys: $\mathrm{U}-\mathrm{Pb}$ age and $\mathrm{Nd}-\mathrm{Sr}$ isotope data from the southern Lancangjiang zone, Yunnan, China. Lithos 113, 408-422.

Huang, J., Chen, G.M., Chen, B.W., 1984. Preliminary analysis of the TethysHimalayan tectonic domain. Acta Geologica Sinica 58, 1-17 (in Chinese with English abstract).

Huang, M.H., Buick, I.S., Hou, L.W., 2003. Tectonometamorphic evolution of the Eastern Tibet Plateau: evidence from the central Songpan-Ganze orogenic belt, western China. Journal of Petrology 44, 255-278.

Huang, T.K., 1945. On major tectonic forms of China. Geological Memoirs of the 
National Geological Survey of China, Series. A, No. 20, 212 (in Chinese with English abstract).

Hutchison, C.S., 1989. Geological Evolution of South-East Asia, Oxford Monographs on Geology and Geophysics, 13. Oxford: Clarendon Press, UK, 368 p.

Ingersoll, R.V., Graham, S.A., Dickson, W.R., 1995. Remnant-ocean basins. In: Busby, C.J. and Ingersoll, R.V. (eds.), Tectonics of Sedimentary Basins. Blackwell Science, Cambridge, MA, 363-391.

Jian, P., Liu, D., Kroner, A., Zhang, Q., Wang, Y.Z., Sun., X.M., Zhang, W., 2009. Devonian to Permian plate tectonic cycle of the Paleo-Tethys Orogen in southwest China (II): Insights from zircon ages of ophiolites, arc/back-arc assemblages and within-plate igneous rocks and generation of the Emeishan CFB province. Lithos, $113,767-784$

Jian, P., Liu, D., Sun, X., 2008. SHRIMP dating of the Permo-Carboniferous Jinshajiang ophiolite, southwestern China: Geochronological constraints for the evolution of Paleo-Tethys. Journal of Asian Earth Sciences 32, 371-384.

Jiang, S.Y., Palmer, M.R., Li, Y.H., Xue, C.J., 1996. Ba-rich micas from the YindongziDaxigou $\mathrm{Pb}-\mathrm{Zn}-\mathrm{Ag}$ and $\mathrm{Fe}$ deposits, Qinling, northwestern China. Mineralogical Magazine 60(400), 433-446.

Kapp, P., Yin, A., Craig, E., Murphy, M., Harrison, T., Spurlin, M., Lin, D., Guang, D.X., Ming, W.C., 2000. Blueschist-bearing metamorphic core complexes in the Qiangtang block reveal deep crustal structure of northern Tibet. Geology 28, 19-22. Kapp, P., Yin, A., Manning, C.E., Harrison, T.M., Taylor, M.H., 2003. Tectonic evolution of the early Mesozoic blueschist-bearing Qiangtang metamorphic belt, central Tibet. Tectonics 22, 1043, doi:10.1029/2002TC001383.

Kröner, A., Zhong, G.W., Sun, Y., 1993. Granulites in the Tongbai area, Qinling belt, China: Geochemistry, petrology, single zircon geochronology, and implications for the tectonic evolution of eastern Asia. Tectonics 12, 245-255.

Lacassin, R., Leloup, P.H., Trinh, P.T., Tapponnier, P., 1998. Unconformity of red sandstones in N. Vietnam: field evidence for Indosinian Orogeny in Northern Indochina? Terra Nova 10, 106-111.

Lepvrier, C., Maluski, H., Tich, V.V., Leyreloup, A., Thi, P.T., Vuong, N.V., 2004. The 
Early Triassic Indosinian orogeny in Vietnam (Truong Son Belt and Kon Tum Massif): Implications for the geodynamic evolution of Indochina. Tectonophysics 393, 87-118.

Lepvrier, C., Maluski, H., Vuong, N.V., Roques, D., Axente, V., Rangin, C., 1997. Indosinian NW-trending shear zones within the Truong Son belt (Vietnam). 40Ar39Ar Triassic ages and Cretaceous to Cenozoic overprints. Tectonophysics 283, 105-127.

Lepvrier, C., Nguyen, V.V., Maluski, H., Thi, P.T., Tich, V.V., 2008. Indosinian tectonics in Vietnam. Comptes Rendu Geoscience 340, 94-111.

Li, C., 1987. The Longmucuo-Shuanghu-Lanchangjiang plate suture and the north boundary of distribution of Gondwana facies Permian-Carboniferous system in northern Xizang, China. Journal of Changchun University of Earth Science 17, 155-166 (in Chinese with English abstract).

Li, C., Zhai, Q.G., Chen, W., Yu, J.J., Huang, X.P., Zhang, Y., 2006b. Ar-Ar chronometry of the eclogite from central Qiangtang area, Qinghai-Tibet Plateau. Acta Petrologica Sinica 22, 2843-2849 (in Chinese with English abstract).

Li, C., Zhai, Q.G., Dong, Y.S., Huang, X.P., 2006a. Discovery of eclogite and its significance from the Qiangtang area, central Tibet. Chinese Science Bulletin 51, 1095- 1100 .

Li, H.Q., Cai, Z.H., Chen, S.Y., Tang, Z.M., Yang, M., 2008. The Indosinian orogenesis occurred in Lhasa terrain and the evidence from muscovite ${ }^{40} \mathrm{Ar} /{ }^{39} \mathrm{Ar}$ geochronology. Acta Petrologica Sinica 24, 1595-1604 (in Chinese with English abstract).

Li, H.Q., Xu, Z.Q., Yang, J.S., Cai, Z., Chen, S., Tang, Z. 2009. Records of Indosinian Orogenesis in Lhasa Terrane, Tibet. Journal of Earth Science 20, 348-363.

Li, X.H., Li, Z.X., Li, W.X, , Wang, Y.J., 2006. Initiation of the Indosinian Orogeny in South China: Evidence for a Permian magmatic arc on Hainan Island. Journal of Geology 114, 341-353.

Li, X.H., Qi, C.S., Liu, Y., Liang, X.R., Tu, X.L., Xie, L.W., Yang, Y.H., 2005. Petrogenesis of the Neoproterozoic bimodal volcanic rocks along the western margin of the Yangtze Block: New constraints from Hf isotopes and Fe/Mn ratios. 
Chinese Science Bulletin 50, 2481-2486.

Li, C., Cheng, L.R., Hu, K. et al., 1995. Study on the paleo-Tethys suture zone of Lungmu Co-Shuanghu, Tibet. Geological Publishing House, Beijing, 1-131(in Chinese with English abstract).

Lin, Y.H., Zhang, Z.M., Dong, X., Xiang, H., Yan, R., 2013. Early Mesozoic metamorphism and tectonic significance of the eastern segment of the Lhasa terrane, south Tibet. Journal of Asian Earth Sciences 78, 160-183.

Liu, B., Feng, Q., Fang, N., Jinhua, J., Fuxiang, H., 1993. Tectonic evolution of PalaeoTethys poly-island-ocean in Changning-Menglian and Lancangjiang belts, southwestern Yunnan, China. Earth Science-Journal of China University of Geosciences 18 (5), 529-538 (in Chinese with English abstract).

Liu, B.T., Jiang, Y.M., Qu, J.C., 1983. The plate tectonics meaning of discovery of the ancient oceanic crust in Sichuan Litang-Ganzi. In: The Qinghai-Tibet Plateau Geological Collection, 12. Geological Publishing House, Beijing, 119 -128 (in Chinese with English abstract).

Liu, C., Deng, J.F., Liu, J.L., Shi, Y.L., 2014. The Characteristics of Volcanic Rocks from Late Permian to Early Traissic in Ailaoshan Tectono-magmatic Belt and Implications for Tectonic Settings.

Liu, C.S., Zhu, J.C., Xu, X.S., Cai, D.K., Yang, P., 1989. The Hercynian collision type granites of east Yunnan and their tectonic significance. Journal of Southeast Asian Earth Science 3, 263-270.

Liu, Z.Q., Xu, X., Pan, G.T,, Li, T.Z., Yu, G.M., Yu, X.J., 1990. Tectonics and Evolution of the Tibetan Plateau. Geological Publishing House, Beijing, (in Chinese with English abstract).

Ma, C.Q., 2011. Reconstruction of Paleo Tethys terrane framework and collisional orogeny of Eastern Kunlun Mountains-Evidence of intrusive work (Unpublished data)

Malavieille, J., Mattauer, M., Lancelot, J., Calassou, S., XU, Z., Hao, Z., 1991. Large scale decollement in the Indosian (Triassic) fold belt of Eastern Tibet. Terra Abstracts 3, 258. 
Mattauer, M., Malavieille, J., Calassou, S., Lancelot, J., Roger, F., Hao, Z., Xu, Z., Hou, L., 1992. La chaîne triasique de Songpan-Ganzi (Quest Sechuan et Est Tibet): une chaîne de plissement-décollement sur marge passive. Comptes rendus de l'Académie des sciences Paris 314, 619-626.

Metcalfe, I., 1999. Gondwana dispersion and Asian accretion: An overview. In: Metcalfe, I. (ed.) Gondwana Dispersion and Asian Accretion, Final Results Volume for IGCP Project 321. Balkema, Rotterdam, 9 - 28.

Metcalfe, I., 1996a. Gondwanaland dispersion, Asian accretion and evolution of Eastern Tethys. Australian Journal of Earth Science 43, 605-623.

Metcalfe, I., 1996b. Pre-Cretaceous evolution of SE Asian terranes. In: Hall, R., Blundell, D. (Eds.), Tectonic Evolution of Southeast Asia: Geological Society London Special Publication 106, 97-122.

Metcalfe, I., 2002. Permian tectonic framework and palaeogeography of SE Asia. Journal of Asian Earth Sciences 20, 551-566.

Metcalfe, I., 2006. Palaeozoic and Mesozoic tectonic evolution and palaeogeography of East Asian crustal fragments: the Korean Peninsula in context. Gondwana Research 9, 24-46.

Metcalfe, I., 2011. Tectonic framework and Phanerozoic evolution of Sundaland. Gondwana Research 19, 3-21.

Metcalfe, I., 2013. Gondwana dispersion and Asian accretion: tectonic and palaeogeographic evolution of eastern Tethys. Journal of Asian Earth Sciences 66, 133.

Miyashiro, A., 1973. The Troodos ophiolitic complex was probably formed in an island arc. Earth Planet Science Letters 19, 218-224.

Mo, X.X., Deng, J.F., Lu, F.X., 1994. Volcanism and the evolution of Tethys in Sanjiang area, southwestern China. Journal of Southeast Asian Earth Sciences 9, $325-333$.

Mo, X.X., Luo, Z.H., Deng, J.F., Yu, X.H., Liu, C.D., Chen, H.W., Yuan, W.M., Liu, Y.H., 2007. Granitoids and crustal growth in the East-Kunlun orogenic belt. Geological Journal of China Universities 13(3), 403-414.

Mock, C., Arnaud, N.O., Cantagrel, J.M., 1999. A nearly unroofing in northeastern Tibet? 
Constraints from ${ }^{40} \mathrm{Ar} /{ }^{39} \mathrm{Ar}$ thermochronology on granitoids from the eastern Kunlun range (Qinghai, NW China). Earth Planet Science Letters 171(1), 107-122.

Morel, P., Irving, E., 1981. Paleomagnetism and the evolution of Pangea. Journal of Geophysical Research 86, 1858-1872.

Nakano, N., Osanai, Y., Owada, M., 2007. Multiple breakdown and chemical equilibrium of silicic clinopyroxene under extreme metamorphic conditions in the Kontum Massif, central Vietnam. American Mineralogist 92, 1844-1855.

Nakano, N., Osanai, Y., Owada, M., Nam, T.N., Tsunogae, T., Toyoshima, T, Binh, P., 2004. Decompression process of mafic granulite from eclogite to granulite facies under ultrahigh-temperature condition in the Kontum massif, central Vietnam. Journal of Mineralogical and Petrological Sciences 99, 242-256.

Nakano, N., Osanai, Y., Sajeev, K., 2010. Triassic eclogite from northern Vietnam: inferences and geological significance. Journal of Metamorphic Geology 28, 59-76.

Nie, S., Yin, A., Rowley, D.B., Jin, Y., 1994. Exhumation of the Dabie Shan ultra-highpressure rocks and accumulation of the Songpan-Ganzi flysch sequence, central Chian. Geology 22 (11), 999-1002.

Osanai, Y., Nakano, N., Owada, M., Nam, T.N., Toyoshima, T., Tsunogae, T., Binh, P., 2004. Permo-Triassic ultrahigh-temperature metamorphism in the Kontum massif, central Vietnam. Journal of Mineralogical and Petrological Sciences 99, 225-241.

Parrish, J.T., 1993. Climate of the supercontinent Pangea. Journal of Geology 101, 215233.

Peng T.P., Wang Y.J., Fan W.M., Liu D.Y, Shi, Y.R., Miao L.C., 2006a. SHRIMP zircon $\mathrm{U}-\mathrm{Pb}$ geochronology of early Mesozoic felsic igneous rocks from the southern Lancangjiang and its tectonic implications. Science in China Series D: Earth Sciences 49, 1032-1042.

Peng, T.P., Wang, Y.J., Fan, W.M., Liu, D.Y., Shi, Y.R., Miao, L.C., 2006b. Early Mesozoic acidic volcanic rocks from the southern Lancangjiang zone: zircon SHRIMP U-Pb geochronology and tectonic implications. Science in China Series D: Earth Sciences 39, 123-132.

Peng, T.P., Zhao, G.C., Fan, W.M., Peng, B.X., Mao, Y.S., 2014. Late Triassic granitic magmatism in the Eastern Qiangtang, Eastern Tibetan Plateau: Geochronology, 
petrogenesis and implication for the tectonic evolution of the Paleo-Tethys. Gondwana Research, in press.

Pullen, A., Kapp, P., Gehrels, G.E., Ding, L., Zhang, Q., 2011. Metamorphic rocks in central Tibet: Lateral variation and implications for crustal structure. Geological Society of America Bulletin 123, 585-600.

Pullen, A., Kapp, P., Gehrels, G.E., Vervoort, J.D., Ding, L., 2008. Closure of the Paleo-Tethys Ocean Triassic continental subduction. Geology 36, 351-354.

Reid, A., Wilson, C.J.L., Shun, L., Pearson, N., Belousova, E., 2007. Mesozoic plutons of the Yidun arc, SW China: U/Pb geochronology and Hf isotopic signature. Ore Geology Review 34, 88-106.

Reid, A.J., Christopher, J.L., Wilson, P.D., Liu, S., 2005a. Mesozoic cooling across the Yidun Arc, central-eastern Tibetan Plateau: A reconnaissance ${ }^{40} \mathrm{Ar} /{ }^{39} \mathrm{Ar}$ study. Tectonophysics 398, 45-66.

Reid, A.J., Christopher, J.L., Wilson, C.J.L., Shun, L., Pearson, N., Belousova, E., 2005b. Mesozoic plutons of the Yidun Arc, SW China: U/Pb geochronology and Hf isotopic signature. Tectonophysics 398, 45-66.

Ren, J.S., Qu, J.C., 1966. On the occurrence of geosynclinal indosinides in the LanpingWeihsi region, western Yunnan. Acta Geological Sinica 46, 182-200 (in Chinese with English abstract).

Roger F, Malavieille J, Leloup PH, Calassou S and Xu Z. 2004. Timing of granite emplacement and cooling in the Songpan-Garzê fold belt (eastern Tibetan Plateau) with tectonic implications. Journal of Asian Earth Science 22, 465-481.

Roger, F., Calassou, S., 1997. U-Pb geochronology on zircon and isotopic geochemistry $(\mathrm{Pb}, \mathrm{Sr}, \mathrm{Nd})$ of basement in the Songpan-Ganzi fold belt (China). Comptes Rendus de L'Academie des Sciences Paris 324, 819-826.

Roger, F., Calassou, S., Lancelot, J., Malavielle, J., Mattauer, M., Xu, Z., Hao, Z., Hou, L., 1995. Miocene emplacement and deformation of the Konga Shan granite (Xianshui He fault, west Sichun, China): geodynamic implications. Earth and Planetary Science Letters 130, 201-216.

Scotese, C.R., 2004. A continental drift flipbook. Journal of Geology 112, 729-741.

She, Z., Ma, C.Q., Roger, M., Li, J.W., Wang, G.C., Lei, Y.H., 2006. Provenance of the 
Triassic Songpan-Ganzi flysch, west China. Chemical Geology 231, 159-175.

Sone, M., Metcalfe, I., 2008. Parallel Tethyan sutures in mainland Southeast Asia new insights for Palaeo-Tethys closure and implications for the Indosinian orogeny. Comptes Rendus Geoscience 340, 166-179.

Tran, V.T., 1979. Explanatory note to the geological map on 1:1,000,000 scale, in: Geology of Vietnam (the North part), Hanoi: Science and Technology Publishing House.

Trung, N.M., Tsujimori, T., Itaya, T., 2006. Honvang serpentinite body of the Song Ma fault zone, Northern Vietnam: A remnant of oceanic lithosphere within the Indochina-South China suture. Gondwana Research 9, 225-230.

Ueno, K., Wang, Y., Wang, X., 2003. Fusulinoidean faunal succession of a PaleoTethyan oceanic seamount in the Changning-Menglian Belt, West Yunnan, Southwest China: An overview, The Island Arc 12, 145-161.

Uysal, İ., Şen, A.D., Ersoy, E.Y., Dilek, Y., Saka, S., Zaccarini, F., Escayola, M., Karslı, O., 2014. Geochemical make-up of oceanic peridotites from NW Turkey and the multi-stage melting history of the Tethyan upper mantle. Mineralogy and Petrology, 108(1), 49-69.

Wang, G.H., Liang, D.Y., Zhang, W.J., Jia, J.C., Zhou, Z.G., Wan, Y.P., Yu, H.L., 2007. Tectono-paleogeographic characteristics in northeastern Tibet, China and spatialtemporal transition of the northern boundary of Gondwana. Geological Bulletin of China 26, $921-928$ (in Chinese with English abstract).

Wang, X., Metcalfe, I., Jian, P., He, L., Wang, C., 2000. The Jinshajiang-Ailaoshan suture zone, China tectonostratigraphy, age and evolution. Journal of Asian Earth Sciences 18, 675-690.

Wang, Y.Z., Bai, Y.S., Lu, H.L., 2001. Geological characteristics of Tianjunnanshan ophiolite in Qinghai and its forming environment. Journal of Qinghai Geology 21(1), 29-35 (in Chinese with English abstract).

Wegener, A. 1912. The origins of continents. Geological Rundschau 3, 276-292 (in German).

Weislogel, A.L., 2008. Tectonostratigraphic and geochronologic constraints on evolution of the northeast Paleotethys from the Songpan-Ganzi complex, central China. 
Tectonophysics 451, 331-345.

Xiao, L., Zhang, H.F., Clemens, J.D., Wang, Q.W., Kan, Z.Z., Wang, K.M., Ni, P.Z., Liu, X.M., 2007. Late Triassic granitoids of the eastern margin of the Tibetan Plateau: geochronology, petrogenesis and implications for tectonic evolution. Lithos 96, 436-452.

Xiong, F., Ma, C., Zhang, J., Liu, B., Jiang, H.A., 2014. Reworking of old continental lithosphere: an important crustal evolution mechanism in orogenic belts, as evidenced by Triassic I-type granitoids in the East Kunlun orogen, Northern Tibetan Plateau. Journal of the Geological Society 171, 847-863.

Xu, Y.H., Harris, N.B.W. Lewis, C.L., 1990. Isotopic geochemistry of the 1985 Tibet Geotraverse: Lhasa to Golmud. In: Sino-British Collaborative Integrated Geological Expedition to Qinghai-Xizang Plateau, Chinese Academy of Sciences: The Geological Evolution of the Tibetan Plateau. Science Press, Beijing, 282-302 (in Chinese with English abstract).

Xu, Y.G., Chung, S.L., Shao, H., He, B., 2010. Silicic magmas from the Emeishan large igneous province, Southwest China: petrogenesis and their link with the endGuadalupian biological crisis. Lithos 119(1), 47-60.

$\mathrm{Xu}$, Z.Q., 1987a. Etude tectonigue et microtectonigue de la chaine paleozoique et triasique des Qinling (Chine). PhD thesis. Montpellier : Academie de Montpellier Université des Sciences et Techniques du Languedoc, 96-98.

Xu, Z.Q., 1987b. Large deep-level decollement structure on the northern margin of the Yangtze plate and its dynamic analysis. Regional Geology of China 4, 289-300 (in Chinese with English abstract).

Xu, Z.Q., Lu, Y.L., Tang, Y.Q., Zhang, Z.T., 1986. The formation of the East Qinling composite mountain chain-deformation, evolution and plate dynamics. China Environment Science Press, Beijing, 1-193 (in Chinese).

Xu, Z.Q., Hou, L.W., Wang, Z.X., 1992. Orogenic Processes of the Songpan-Ganzi Orogenic Belt of China. Geological Publishing House, Beijing, 1-190 (in Chinese).

Xu, Z.Q., Yang, J.S, Chen, W., Guo, C.F., 1997. Mesozoic Crustal Evolution and Dynamics of the East Kunlun-Taggula Composite Mountain Chains. Proceedings of the 30th International Geological Congress 7, 7-20. 
Xu, Z.Q., Jiang, M., Yang, J.S., 1999. Mantle diapir inward intracontinental subduction: A discuss on the mechanism of uplift of the Qinghai-Tibet plateau. Geological Society of America, Special Paper 328,19-31.

Xu, Z.Q., Yang, J.S., Li, H.B., Zhang, J.X., Wu, C.L., 2007. Orogenic Plateau: Terrane Amalgamation, Collision and Uplift in the Qinghai-Tibet Plateau. Geological Publishing House, Beijing, 1-458 (in Chinese with English abstract).

Xu, Z.Q., Yang, J.S., Li, H.Q., Wang, R.R., Cai, Z.H., 2012. Indosinian collisionorogenic system of Chinese continent and its orogenic mechanism. Acta Petrologica Sinica 28, 1697-1709.

Xu, Z.Q., Wang, Q., Arnaud, P., Liang, F.H., Qi, X.X., Cai, Z.H., Li, H.Q., Zeng, L.S., Cao, H., 2013. Orogen-parallel ductile extension and extrusion of the Greater Himalaya in the late Oligocene and Miocene. Tectonics 32, 1-25.

XZBGM (Bureau of Geology and Mineral Resources of Xizang Autonomous Region), 1993. Regional Geology of Xizang (Tibet) Autonomous Region. Geological Publishing House, Beijing (in Chinese with English abstract).

Yan, Z., Wang, Z.Q., Li, J.L., Xu, Z.Q., Deng, J.F., 2012. Tectonic settings and accretionary orogenesis of the West Qinling Terrane, northeastern margin of the Tibet Plateau. Acta Petrologica Sinica 28( 6), 1808 - 1828

Yang, J.S., Robinson, P.T., Jiang, C.F., Xu, Z.Q., 1996. Ophiolites of the Kunlun Mountains, China and their tectonic implications. Tectonophysics 258, 215-231.

Yang, J.S., Xu, Z.Q., Li, H.B., Wu, C.L., Cui, J.W., Zhang, J.X., Chen, W., 1998. Discovery of eclogite at northern margin of Qaidam Basin, NW China. Chinese Science Bulletin 43, 1755-1760.

Yang, J.S., Xu, Z.Q., Geng, Q.R., Li, Z.L., Xu, X.Z., Li, T.F., Ren, Y.F., Li, H.Q., Cai, Z.H., Liang, F.H., Chen. S.Y., 2006. A possible new HP/UHP metamorphic belt in China: Discovery of eclogite in the Lhasa Terrane, Tibet. Acta Petrologica Sinica 80, 1787-1792 (in Chinese with English abstract).

Yang, J.S., Xu, Z.Q., Li, T.F., Li, H.Q., Li, Z.L., Ren, Y.F., Xu, X.Z., Chen, S.Y., 2007. Oceanic subduction-type eclogite in the Lhasa block, Tibet, China: Remains of the Paleo-Tethys ocean basin? Geological Bulletin of China 26, 1277-1287 (in Chinese with English abstract). 
Yang, T.N., Zhang, H.R., Liu, Y.X., Wang, Z.L., Song, Y.C., Yang, Z.S., Tian, S.H., Xie, H.Q., Hou, K.J., 2011. Permo-Triassic arc magmatism in central Tibet: evidence from zircon $\mathrm{U}-\mathrm{Pb}$ geochronology, $\mathrm{Hf}$ isotopes, rare earth elements, and bulk geochemistry. Chemical Geology 284, 270-282.

Zhai, Q.G., Jahn, B.M., Su, L., Ernst, R.E., Wang, K.L, Zhang, R.Y, Wang, J., Tang, S., 2013c. SHRIMP zircon U-Pb geochronology, geochemistry and Sr-Nd-Hf isotopic compositions of a mafic dyke swarm in the Qiangtang terrane, northern Tibet and geodynamic implications. Lithos 174, 28-43.

Zhai, Q.G., Jahn, B.M., Su, L., Jun, W., Mo, X.X., Lee, H.Y., Wang, K.L, Tang. S., 2013a. Triassic arc magmatism in the Qiangtang area, northern Tibet: Zircon U-Pb ages, geochemical and Sr-Nd-Hf isotopic characteristics, and tectonic implications. Journal of Asian Earth Sciences 63, 162-178.

Zhai, Q.G., Jahn, B.M., Su, L., Wang, J., Mo, X.X., Lee, H.Y., Wang, K.L, Tang. S., 2013b.The Carboniferous ophiolite in the middle of the Qiangtang terrane, Northern Tibet: SHRIMP U-Pb dating, geochemical and Sr-Nd-Hf isotopic characteristics. Lithos 168-169, 186-199.

Zhai, Q.G., Jahn, B.M., Zhang, R.Y., Wang, J., Su L., 2011a. Triassic subduction of the Paleo-Tethys in northern Tibet, China: Evidence from the geochemical and isotopic characteristics of eclogites and blueschists of the Qiangtang Block. Journal of Asian Earth Sciences 42, 1356-1370.

Zhai, Q.G., Li, C., Huang, X.P., 2007. The fragment of Paleo-Tethys ophiolite from central Qiangtang, Tibet: geochemical evidence of metabasites in Guoganjianian. Science in China Series D-Earth Sciences 50, 1302-1309.

Zhai, Q.G., Wang, J., Li, C., Su, L., 2010. SHRIMP U-Pb dating and Hf isotopic analyses of Middle Ordovician meta-cumulate gabbro in central Qiangtang, northern Tibetan Plateau. Science in China-Earth Sciences 53, 657-664 (in Chinese with English abstract).

Zhai, Q.G., Zhang, R.Y., Jahn, B.M., Li, C., Song, S.G., Wang, J., 2011b. Triassic eclogites from central Qiangtang, northern Tibet, China: Petrology, geochronology and metamorphic P-T path. Lithos 125, 173-189.

Zhang, H.F., Parrish, R., Zhang, L., Xu, W.C., Yuan, H.L., Gao, S., Crowley, Q.G., 2007. 
A-type granite and adakitic magmatism association in Songpan-Ganzi fold belt, eastern Tibetan Plateau: implication for lithospheric delamination. Lithos 97, 323335.

Zhang, H.F., Zhang, L., Harris, N., Jin, L., Yuan, H.L., 2006. U-Pb zircon ages, geochemical and isotopic compositions of granitoids in Songpan-Ganzi fold belt, eastern Tibetan Plateau: constraints on petrogenesis and tectonic evolution of the basement. Contributions to Mineralogy and Petrology 152, 75-88.

Zhang, K.J., Cai, J.X., Zhang, Y.X., Zhao, T.P., 2006b. Eclogites from central Qiangtang, northern Tibet (China) and tectonic implications. Earth and Planetary Science Letters 245, 722-729.

Zhang, K.J., Tang, X.C., Wang, Y., Zhang, Y.X., 2011. Geochronology, geochemistry, and $\mathrm{Nd}$ isotopes of early Mesozoic bimodal volcanism in northern Tibet, Western China: constraints on the exhumation of the central Qiangtang metamorphic belt. Lithos 121, 167-175.

Zhang, K.J., Zhang, Y.X., Li, B., Zhu, Y.T. Wei, R.Z., 2006a. The blueschist-bearing Qiangtang metamorphic belt (northern Tibet, China) as an in situ suture zone: Evidence from geochemical comparison with the Jinsa suture. Geology 34, 493-496. Zhang, K.J., Zhang, Y.X., Tang, X.C., Xia, B.D., 2012. Late Mesozoic tectonic evolution and growth of the Tibetan plateau prior to the Indo-Asian collision. Earth-Science Reviews 114, 236-249.

Zhang, L.Y., Lin, D., Pullen, A., Xu, Q., Liu, D.L., Cai, F.L., Yue, Y.H., Lai, Q.Z., Shi, R.D., Ducea, M.N., Kapp, P., Chapman, A., 2014. Age and geochemistry of western Hoh-Xil-Songpan-Ganzi granitoids, northern Tibet: Implications for the Mesozoic closure of the Paleo-Tethys ocean. Lithos 190-191, 328-348.

Zhang, R.Y., Lo, C.H., Chung, S.L., Grove, M., Omori, S., Iizuka,Y., Liou, J, G., Tri, T.V., 2013. Origin and tectonic implication of ophiolite and eclogite in the Song Ma Suture Zone between the South China and Indochina Blocks. Journal of Metamorphic Geology 31, 49-62, doi: 10.1007/s11430-006-1032-y

Zhang, Z.M., Dong, X., Xiang, H., Liou, J. G., Santosh, M., 2013. Building of the Deep Gangdese Arc, South Tibet: Paleocene Plutonism and Granulite-Facies Metamorphism. Journal of Petrology 54, 2547-2580. 
Zhang, Z.M., Jin, M. 1979. Two kinds of melange and their tectonic significance in Xiangcheng-Derong area, southwestern Sichuan. Chinese Journal of Geology 85, 205-216 (in Chinese with English abstract).

Zhao, S.W., Lai, S.C., Qin, J.F., Zhu, R.Z., 2014. Zircon U-Pb ages, geochemistry, and $\mathrm{Sr}-\mathrm{Nd}-\mathrm{Pb}-\mathrm{Hf}$ isotopic compositions of the Pinghe pluton, Southwest China: implications for the evolution of the early Palaeozoic Proto-Tethys in Southeast Asia. International Geology Review (ahead-of-print), 1-20.

Zhong, D.L., 1998. The Paleotethys orogenic belt in west of Sichuan and Yunnan. Science Publishing House, Beijing 1-230 (in Chinese with English abstract).

Zhou, D., Graham, S.A., 1996. The Songpan-Ganzi complex of the western Qinling Shan as a Triassic remnant ocean basin. In: Yin, A., Harrison, T.M. (Eds.), The Tectonic Evolution of Asia. Cambridge University Press, Cambridge, 281-299.

Zhou, J.B., Wilde, S.A., Zhao, G.C, Zheng, C.Q., Jin, W., Zhang, X.Z. Cheng, H., 2008. Detrital zircon U-Pb dating of low-grade metamorphic rocks in the Sulu UHP belt: evidence for overthrusting of the North China Craton onto the South China Craton during continental subduction. Journal of the Geological Society 165, 423-433.

Zhou, M.F., Yan, D.P., Kennedy, A.K., Li, Y., Ding, J., 2002. SHRIMP U-Pb zircon geochronological and geochemical evidence for Neoproterozoic arc magmatism along the western margin of the Yangtze Block, South China. Earth and Planetary Science Letters 196, 51-67.

Zhou, M.F., Ma, Y., Yan, D.P., Xia, X., Zhao, J.H., Sun, M., 2006a. The Yanbian Terrane (Southern Sichuan Province, SW China): A Neoproterozoic arc assemblage in the western margin of the Yangtze Block. Precambrian Research 144, 19-38.

Zhou, M.F., Yan, D.P., Wang, C.L., Xia, X., Zhao, J.H., Sun, M., 2006b. Subductionrelated origin of the $750 \mathrm{Ma}$ Xuelongbao adakitic complex (Sichuan Province, China): implications for the tectonic setting of the giant Neoproterozoic magmatic event in South China. Earth and Planetary Science Letters 248, 286-300.

Zhu, J.J., Hu, R.Z., Bi, X.W., Zhong, H., Chen, H., 2011. Zircon U-Pb ages, Hf-O isotopes and whole-rock $\mathrm{Sr}-\mathrm{Nd}-\mathrm{Pb}$ isotopic geochemistry of granitoids in the Jinshajiang suture zone, SW China: Constraints on petrogenesis and tectonic evolution of the Paleo-Tethys Ocean. Lithos 126, 248-264. 


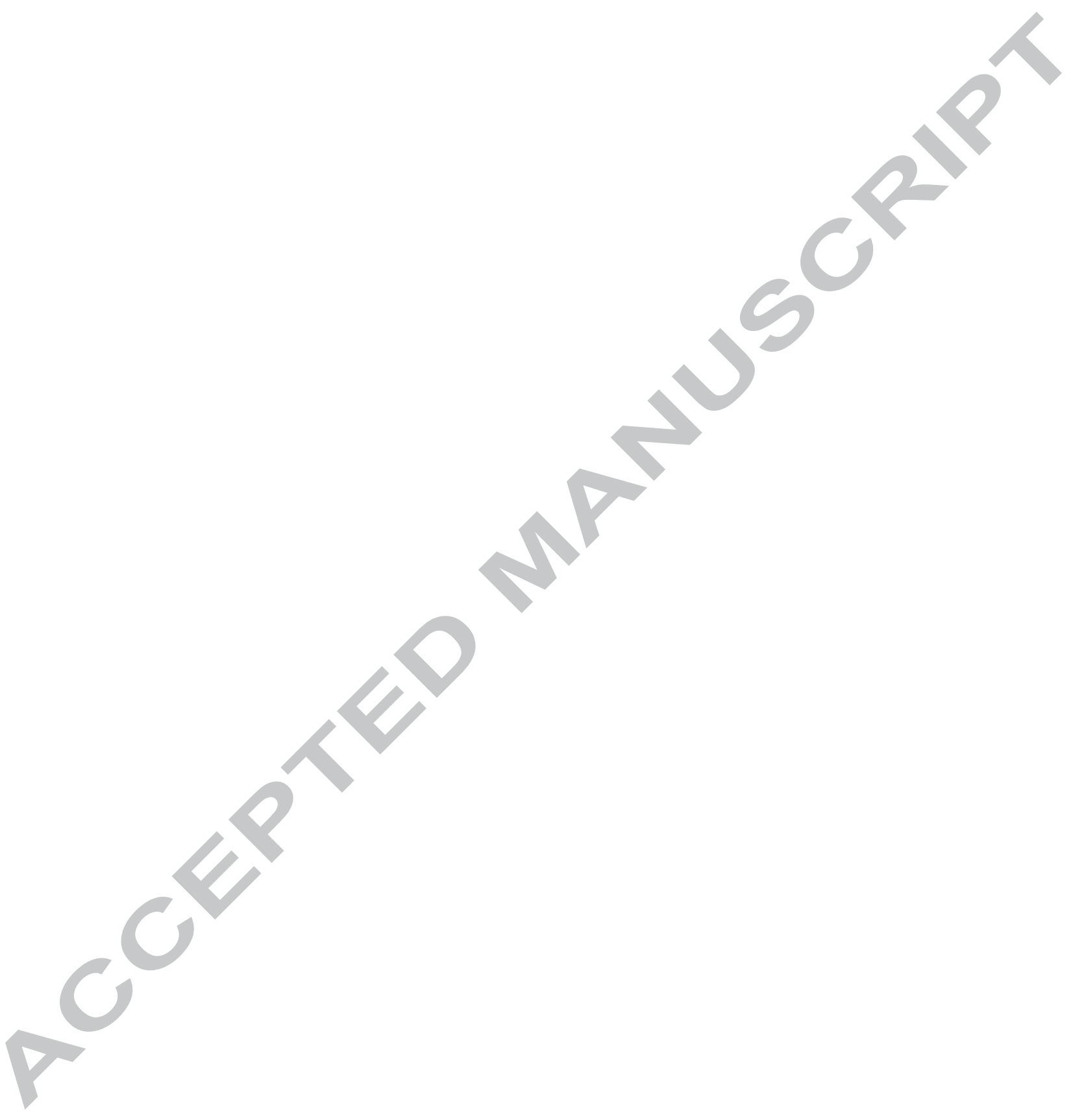




\section{Figure Captions}

Figure 1. Paleogeographic reconstructions of the Tethyan region for late Permian (A) and late Triassic (B), showing relative positions of the west and southeast Asian terranes and distribution of the landmasses and sea during these time periods (after Scotese, 2004).

Key to lettering: SC-South China; I-Indochina; NC-North China; SB-Sibumasu; WBWest Burma; QT-Qiangtang; L-Lhasa; WC-Western Cimmerian Continent, SG-Songpan Ganze.

Figure 2. Schematic Permian paleogeographic reconstruction of northern PeriGondwana and Paleo-Tethys with a focus on the crustal blocks in Tibet. A. Samarian; B. Artinskian; C. Capitanian; D. Changhsingian (after Metcalfe, 2002).

Tectonic blocks: Ar-Arabia; B-Baoshan; IC-Indochina; Ir-Iran; L-Lhasa; SC-South China; Qi-Qiangtang; SB-Sibumasu; SA-South Afghanistan; SP-South Pamir; CPCentral Pamir; Qa-Qamdo; T- Tengchong; Si- Simao; Tu-Turkey; H-Himalaya.

Figure 3. Simplified tectonic map with age data, showing the Paleo-Tethyan system in the East Cimmerides and West Cathaysides in Tibet (Sources of the age data: Triassic granitoids in SPGZ are from Roger et al., 2004; Zhang et al., 2006; and Yuan et al., 2010).

Blocks and terranes: NCB: North China Block; SCB: South China Block; TRMB: Tarim Block; IDB: India Block; EKL-QDM-QL: East Kunlun-Qaidam-Qilian terrane; WKL: West Kunlun terrane; SPGZ: Songpan-Ganze terrane; NQT-QD-SM-IC: North Qiangtang-Qamdo-Simao-Indochina terrane; SQT-BS-SB: South Qiangtang-BaoshanSibumasu terrane; NLS: North Lhasa terrane; SLS: South Lhasa terrane; TC: Tengchong terrane; TSH: Tianshuihai terrane; WB: West Burma terrane.

Suture zones: EKL-ANMQS: East Kunlun-A'nyemaqen Suture; WKLS: West Kunlun Suture; LTS: Litang Suture; JSJ-ALS-SMS: Jinshajiang-Ailaoshan-Song Ma Suture; LS 
-CM-INS: Longmu Tso Shuanghu-Changning Menglian-Inthanon Suture; JH-NU-SKS: Jinghong-Nan Uttaradit-Sra Kaeo Suture; BNS: Bangonghu-Nujiang Suture; SQH-JLS: Siquanhe-Jiali Suture; SDS: Sumdo Suture; ITS: Indus-Tsangbo Suture; WQL: West Qinling; YD: Yidun Arc.

Arc terranes: BHDA: Bulhanbuda Arc terrane; YDA: Yidun Arc terrane; LC-ST-CBA: Lincang-Sukhothai-Chanthaburi Arc terrane; KHA: Kohistan Arc terrane; LDA: Ladakh arc terrane; WQL: West Qinglin terrane

Faults: ALTF: Altyn Tagh Fault; NQLT: North Qilian Thrust; LMST: Longmenshan Thrust; RRF: Red River Fault; KKF: Karakurum Fault; MFT: Main Frontal Thrust; SGF: Sagaing Fault; GLGF: Gaoligong Fault.

Figure 4. Cross-sections of the Yidun Arc Terrane (4A), and the A'nyemaqen Suture Zone (4B).

Figure 5. Simplified geological map of the Bulhabuda magmatic arc terrane at the northern active margin of the East Kunlun-A'nyemaqen branch of the Paleo-Tethyan Ocean.

Figure 6. Tectonic map of the West Qinling accretionary prism complex north of the A’nyemaqen suture zone.

Figure 7. Simplified tectonic map of the Sumdo subduction complex in the South Qiangtang-Lhasa terrane.

Figure 8. Simplified tectonic map showing the Paleo-Tethyan system and the Triassic orogens along the western and northern margins of the South China Block.

Key to lettering: ELK-QDM-QL-NQL: East Kunlun-Qaidam-Qilian-North Qinling terrane; NCB: North China Block; SPGZ: Songpan Ganze terrane; SQL: South Qinling Orogen; NQT: North Qiangtang; QD: Qamdo; SM: Simao; IC: Indochina; SQT-NLS: South Qiangtang-North Lhasa; SLS: South Lhasa; HM: Himalaya; TC-BS: TengchongBaoshan; SB: Sibumasu; EKL-ANMQS: East Kunlun-A'nyemaqen Suture; LM-CMS: 
Longmu Ttso Shuanghu-Changning Menglian Suture; JH-Jinghong Suture; SDS: Sumdo Suture; BNS-Bangonghu Nujiang Suture; ITS: Indus-Tsangpo Suture; SQL: South Qinling terrane; SPGZ: Songpan Ganze terrane; NV: North Vietnam terrane.

Figure 9. Schematic Tectonic Map (A), and cross-section (B) of the Songpan-Ganze orogen in the northwestern South China block. Key to lettering: Bi-biotite; Ch-chlorite; Ky-kyanite ; Ga-garnet; Sil-sillimanite ; St-staurolite;

QT-Qiangtang; EKL-East Kunlun; SCB-South China block; DBD-Danba detachment.

Figure 10. Schematic Tectonic Map (A), and cross-section (B) of the South Qinling orogen in the Northern South China block. Key to lettering: DFF-Dangfen Fault; FXFFangxian Fault; SYF-Shanyang Fault.

Figure 11. Sequential tectonic model for the evolution of the Paleo-Tethyan realm in Tibet. Key to lettering: LS-Lhasa; SD-Sumdo; JSJ-Jinshajiang; ANMQ-A'nyemaqen; BN-Bangong Nujiang Suture Zone; SLS-South Lhasa; NLS-North Lhasa; SQT-South Qiangtang; NQT-North Qiangtang; SP-Songpan; EKL-East Kunlun; CC-Continental Crust; LM-lithospheric Mantle. 

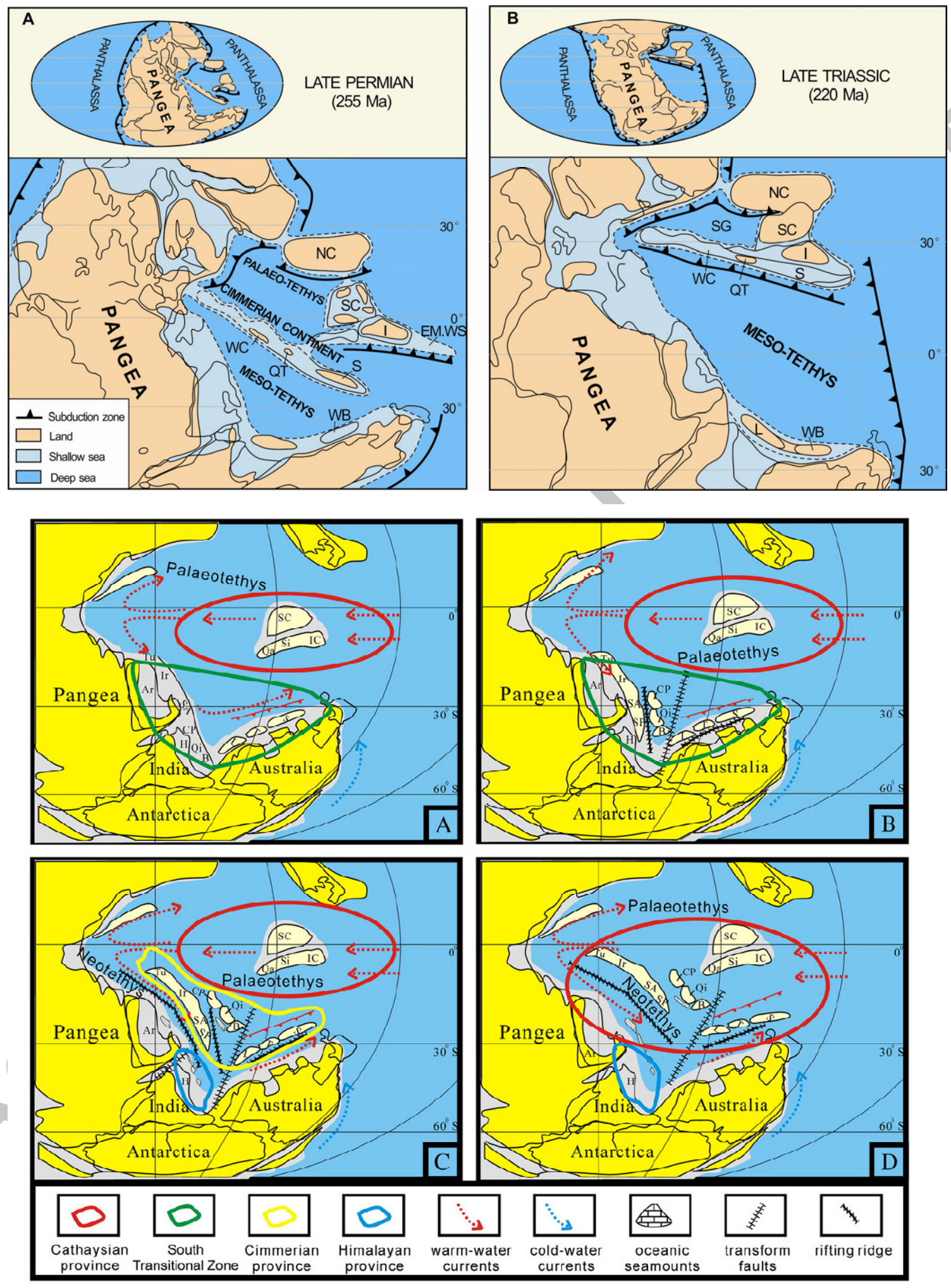


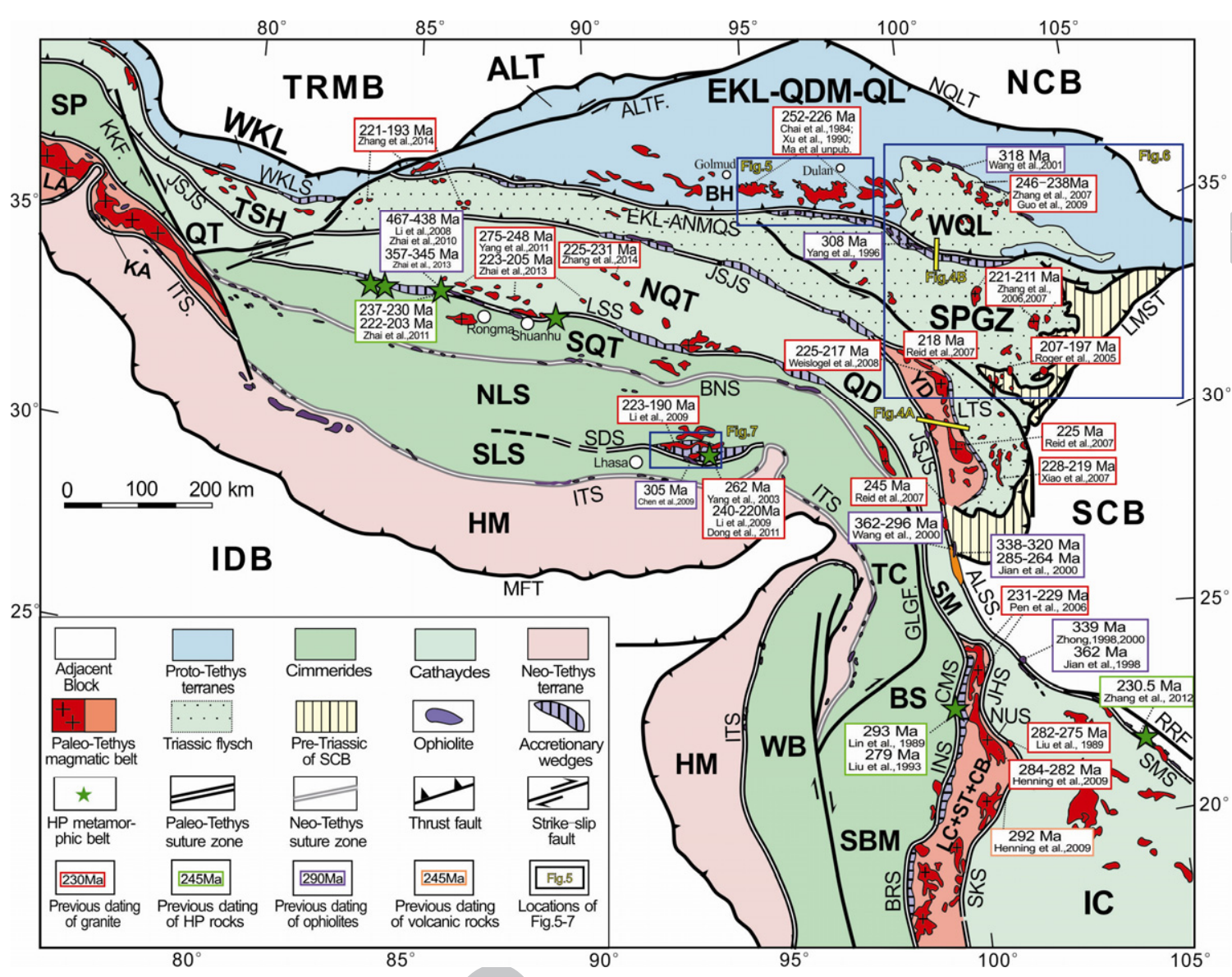

NW

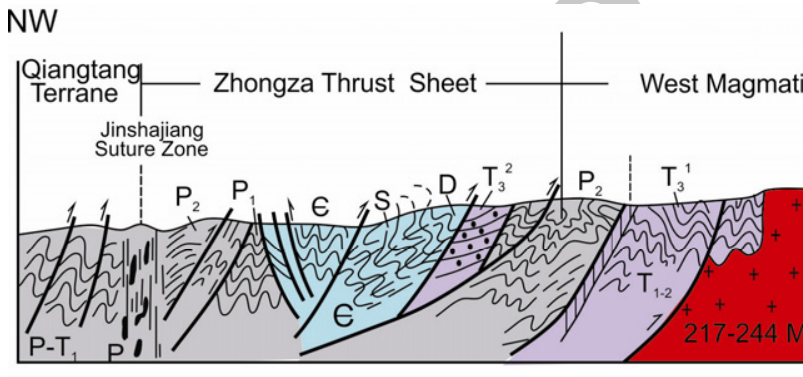

Yidun Arc Terrane

\section{Songpan Ganze Terrane A'nyemagen}

East Kunlun Terrane
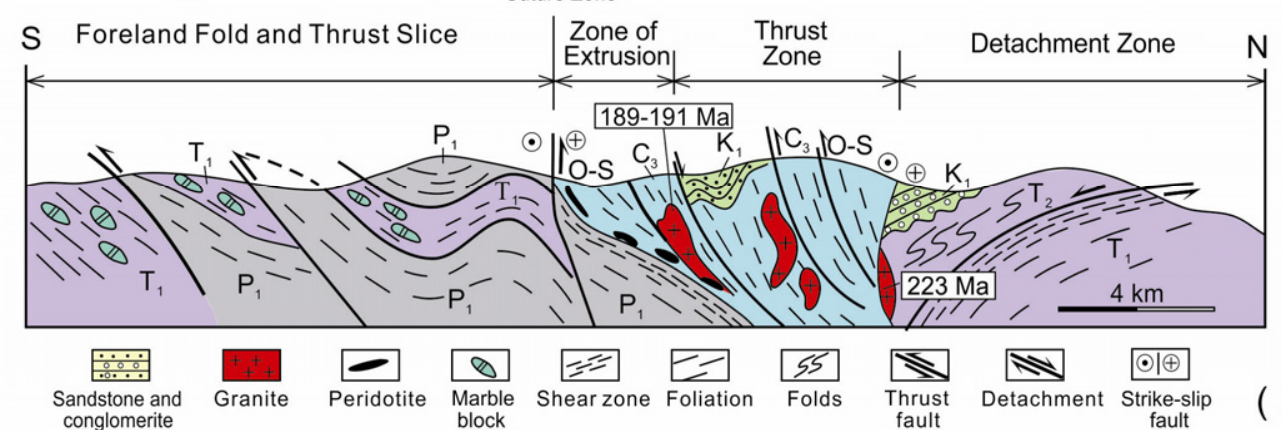

( B ) 


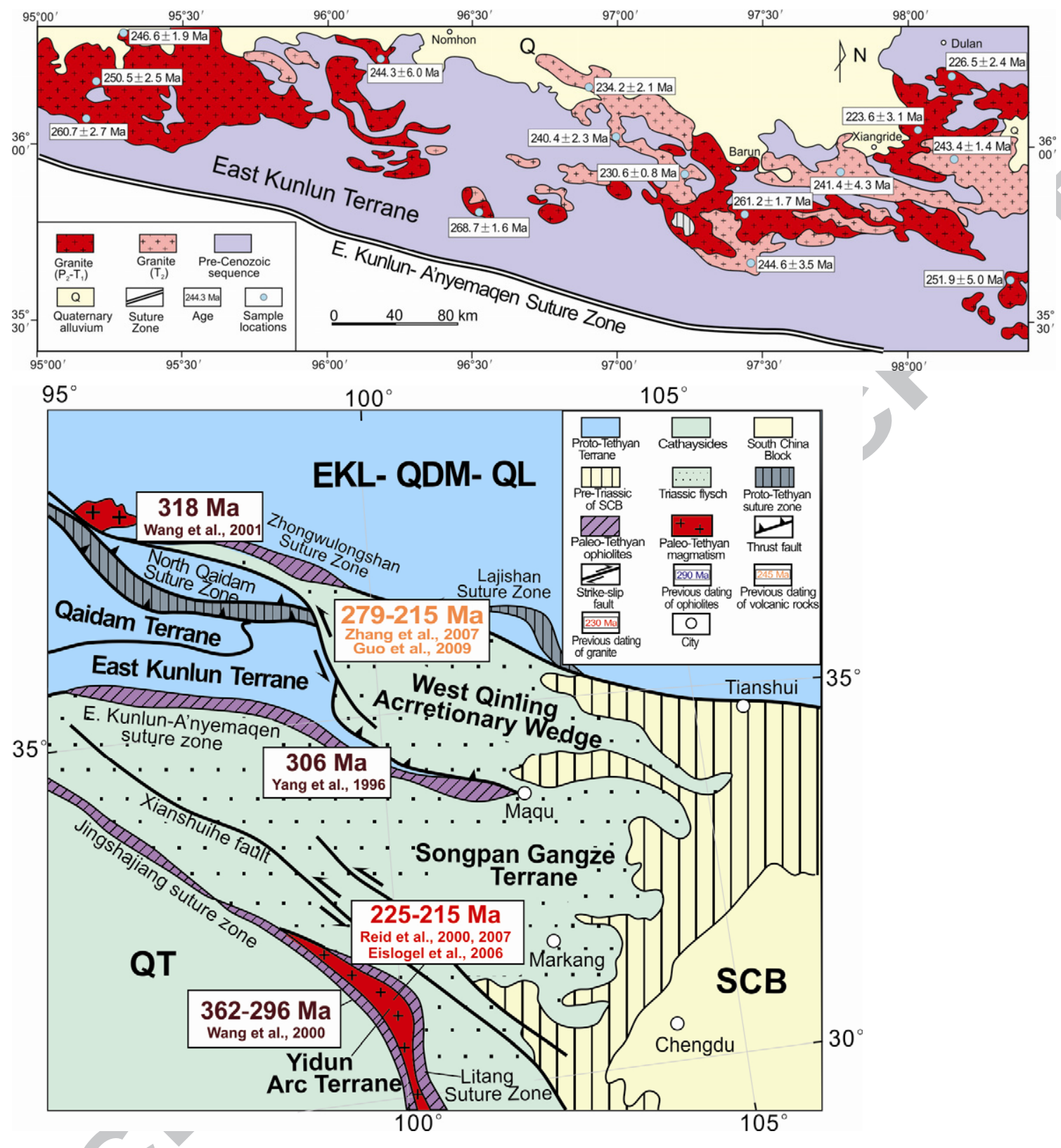



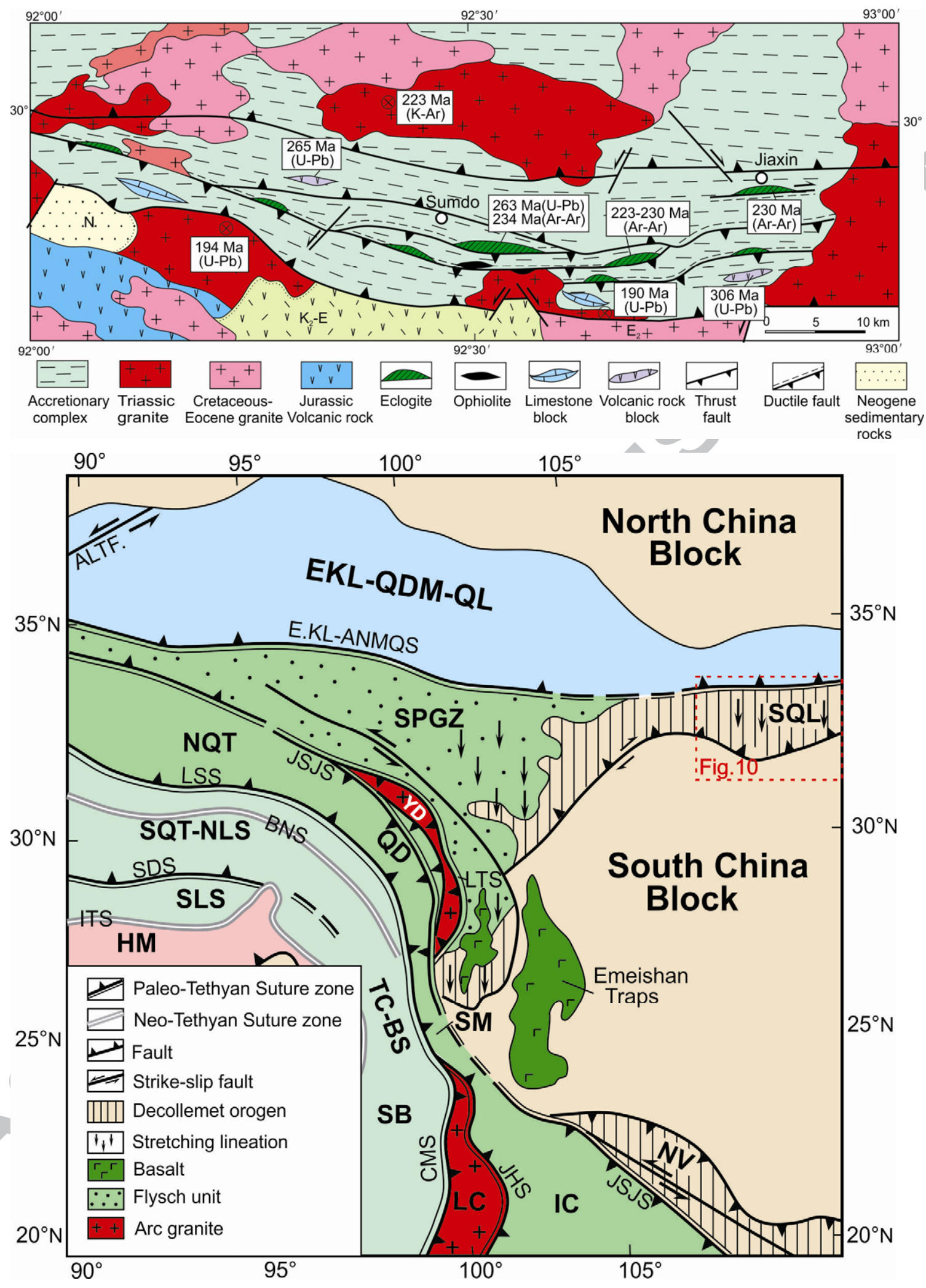

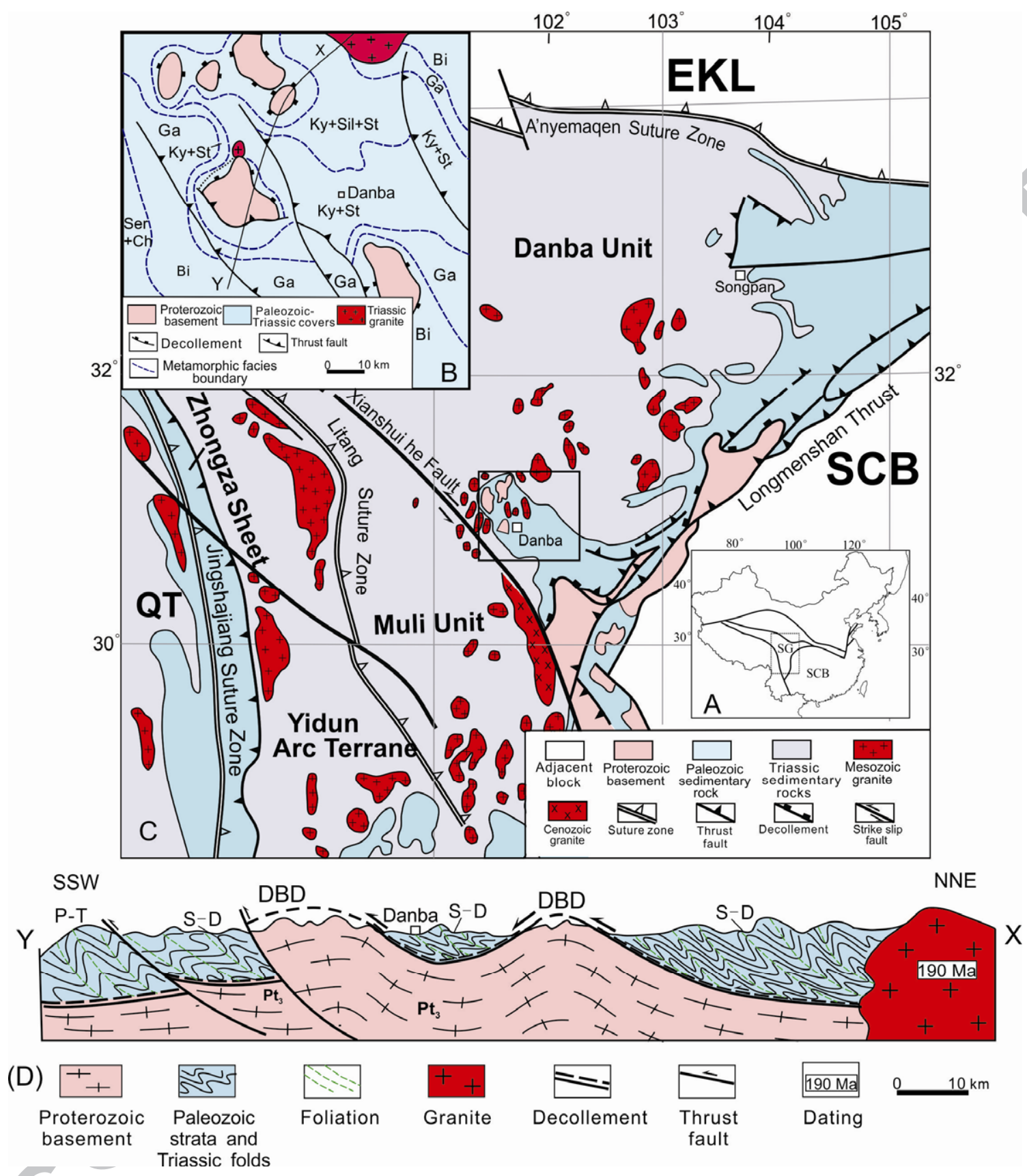

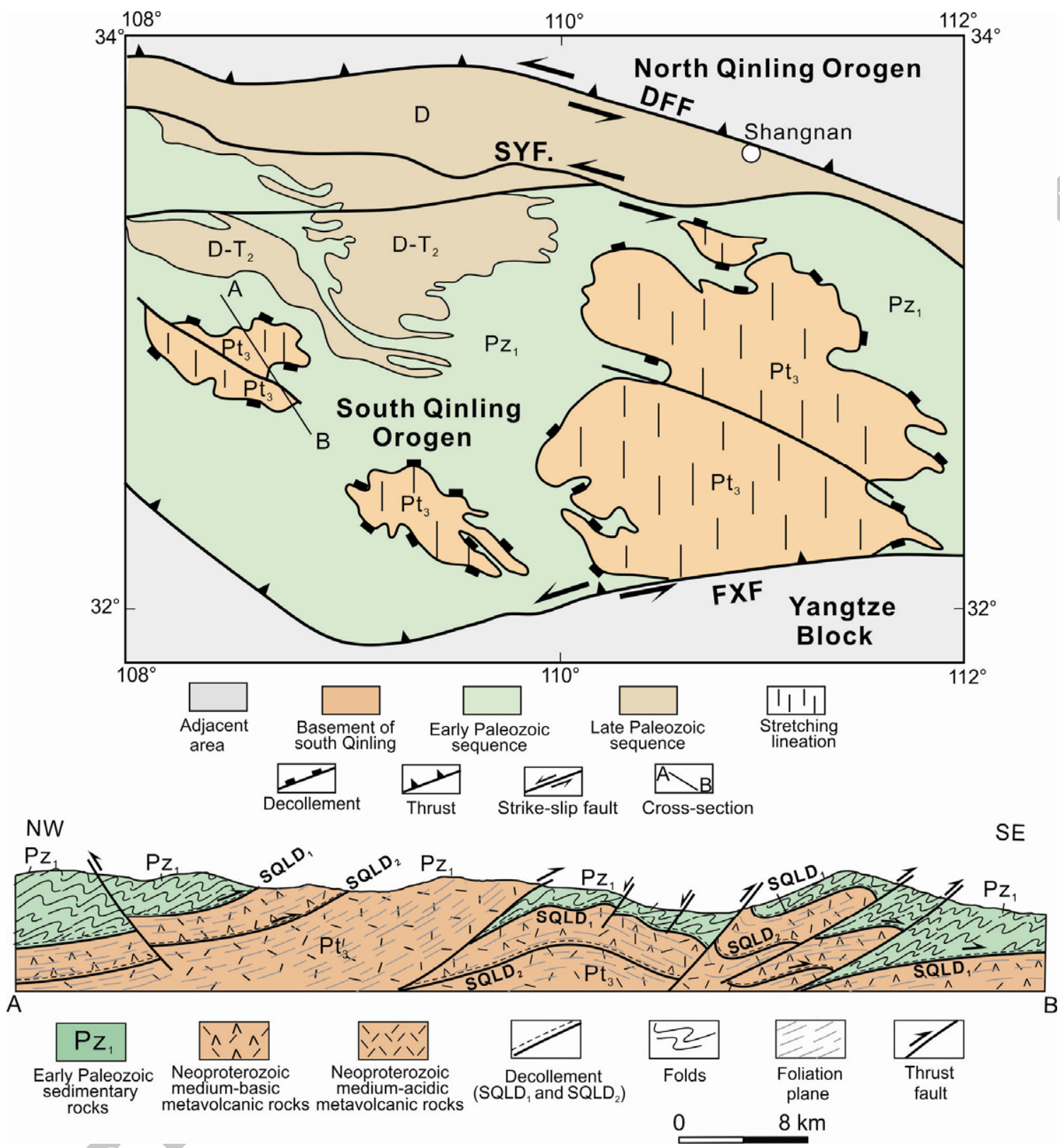

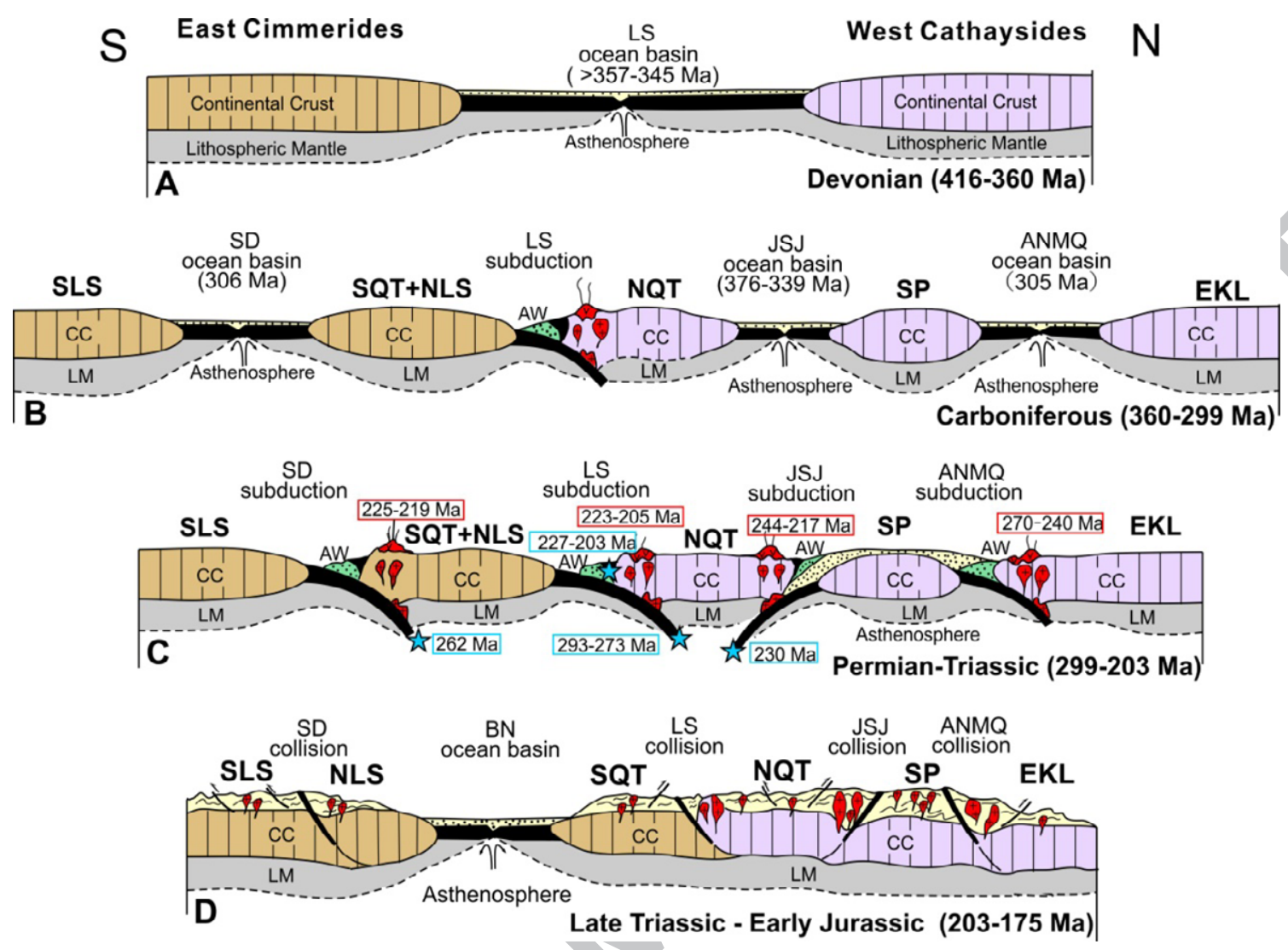

Highlights:

1. Paleo-Tethys system in Tibet consists of multi-terranes in East Cimmerides and West Cathaysides;

2. Longmucuo Shuanghu-Changning Menglian suture zone was the main suture zone;

3. Jinshajiang-Ailaoshan oceanic subduction shows a "trench-ridge- trench" triple junction model;

4. Decollement-type orogens occurred at western passive margin of South China Block 


\section{Paleo-Tethyan Evolution of Tibet as Recorded in the East Cimmerides and West Cathaysides}

Zhiqin $\mathrm{Xu}^{\mathrm{a}, \mathrm{b}_{*}}$, Yildirim Dilek ${ }^{\mathrm{a}, \mathrm{c}}$, Hui Cao ${ }^{\mathrm{a}}$, Jingsui Yang ${ }^{\mathrm{a}}$, Paul Robinson ${ }^{\mathrm{d}}$, Changqian $\mathrm{Ma}^{\mathrm{e}}$, Huaqi $\mathrm{Li}^{\mathrm{a}}$, Marc Jolivet ${ }^{\mathrm{f}}$, Françoise Roger ${ }^{\mathrm{g}}$, Xijie Chen ${ }^{\mathrm{a}}$

${ }^{a}$ State Key Laboratory of Continental Tectonics and Dynamics, Institute of Geology, Chinese Academy of Geological Sciences, Beijing 100037, China

${ }^{\mathrm{b}}$ State Key Laboratory for Mineral Deposits Research, Department of Earth Sciences, Nanjing University, Nanjing 210093, China

'Department of Geology \& Environmental Earth Science, Miami University, Oxford, OH 45056, USA

${ }^{\mathrm{d} D e p a r t m e n t ~ o f ~ E a r t h ~ S c i e n c e s, ~ D a l h o u s i e ~ U n i v e r s i t y, ~ H a l i f a x, ~ N o v a ~ S c o t i a, ~ C a n a d a ~}$ B3H4J1

${ }^{\mathrm{e}}$ China University of Geosciences, Wuhan 430074, China

${ }^{\mathrm{f}}$ UMR 6118 - CNRS - University Rennes 1, Campus de Beaulieu, 35042 RENNES Cédex, France

${ }^{g}$ Université Montpellier 2, Place Eugène Bataillon, 34095 Montpellier Cedex 05, France

\section{Corresponding Author:}

Dr. Zhiqin Xu

Tel.: +86-01068999663

Email: xuzhiqin@gmail.com

\section{Submitted to:}

Journal of Asian Earth Sciences 